NBER WORKING PAPER SERIES

\title{
THE ECONOMICS OF LATIN AMERICAN ART: CREATIVITY PATTERNS AND RATES OF RETURN
}

\author{
Sebastian Edwards \\ Working Paper 10302 \\ http://www.nber.org/papers/w10302 \\ NATIONAL BUREAU OF ECONOMIC RESEARCH \\ 1050 Massachusetts Avenue \\ Cambridge, MA 02138 \\ February 2004
}

This is a revised and shorter version of the Presidential Address I delivered at the Latin American and Caribbean Economics association (LACEA) annual meetings in Puebla (Mexico), on October 27 $7^{\text {th }}, 2003$. I have benefited from discussion with Ed Leamer, Alejandra Cox Edwards, Manuelita Ureta, Eduardo Lora and Fernando Losada. I thank Andrés Velasco for his comments. Lourdes Pineda provided wonderful research assistance. I am grateful to UCLA's Anderson School of Management CIBER program for financial support. The views expressed herein are those of the authors and not necessarily those of the National Bureau of Economic Research.

(C)2004 by Sebastian Edwards. All rights reserved. Short sections of text, not to exceed two paragraphs, may be quoted without explicit permission provided that full credit, including (C) notice, is given to the source. 
The Economics of Latin American Art: Creativity Patterns and Rates of Return Sebastian Edwards

NBER Working Paper No. 10302

February 2004

JEL No. J24, O54, N26, G12, G15

\section{$\underline{\text { ABSTRACT }}$}

In this paper I use a large data set to analyze two aspects of the Latin American arts: (1) the nature of artistic creative process, and (2) Latin American art as an investment. I use data on auctions to understand the relation between artists", age and the value of their work. The analysis on creativity suggests that Latin American artists have followed very different patterns from that followed by U.S. artists. There is strong evidence suggesting that American artists born after 1920 did their best work at an earlier age than their older colleagues; exactly the opposite is true for the case of Latin America. Indeed, the results reported in this paper suggest that Latin American artists born after 1920 did their best work at a significantly older age than their colleagues from earlier cohorts. The analysis of art as an investment is based on the estimation of hedonic price indexes, and indicates that Latin American art has had a relatively high rate of return - indeed much higher than that of other type of paintings. The results also indicate that returns on Latin American art have a very low degree of correlation - that is, a very low beta - relative to an international portfolio comprised of equities. This means that adding Latin American art will lower the overall risk of an international portfolio.

Sebastian Edwards

UCLA Anderson Graduate School of Business

110 Westwood Plaza, Suite C508

Box 951481

Los Angeles, CA 90095-1481

and NBER

sedwards@anderson.ucla.edu 


\section{Introduction}

The Latin American countries are famously known for their economic and political travails. Most of the region has been characterized by a long history of authoritarian politicians, successive coup d'etat, galloping inflation and financial crises. The literature attempting to explain Latin America's political and economic developments - or lack thereof - is voluminous and covers most angles of the region's social problems.

Politics and economics, however, are not the only aspects of the Latin American nations that have attracted the attention of intellectuals from around the world. Indeed, there has traditionally been keen interest in Latin American literary and artistic accomplishments. For example, the works of novelists Gabriel García Márquez, and Mario Vargas Llosa, and of poets Pablo Neruda and Octavio Paz have been exhaustively analyzed by critics and academics, as have the works of artists Frida Khalo, Diego Rivera and Fernando Botero.

Studies on Latin American economic and artistic developments have proceeded along separate paths. Very few economists - if any - have used economic methods and data to analyze issues related to the Latin American literature or arts. And only a few authors - mostly of a Marxist persuasion - have attempted to relate the creative process to the region's economic developments or prospects.

In this paper I use a large data set and economic methods to analyze two (rather different) aspects of the Latin American arts: (1) the nature of artistic creative process, and (2) Latin American art as an investment. I am particularly interested in using data on art auctions to understand the relation between artists' age and the evolution of their work. I also use these data to investigate the historical rates of return obtained by buyers of Latin American art. This research is part of a new and growing field on the economics of art and cultural economics, whose pioneers include William Baumol, Richard Caves, Orley Ashenfelter, Bruno Frey, Victor Ginsburgh and David Galenson, among others. ${ }^{1}$

Besides the intrinsic interest of the subject, Latin American art auctions have a number of advantages as a subject of study. First, there have been regular and dedicated

\footnotetext{
${ }^{1}$ The number of authors using data on auctions to analyze the art market is growing rapidly. For a list of contributors to this literature see, for example, the recent review by Ashenfelter and Graddy (2003).
} 
international auctions for Latin American art since 1979. Although Sotheby's and Christie's dominate the market, a number of smaller houses are quite active, both in Europe and in the United States. Second, museum activity in this area of collecting is still limited. Thus - and in contrasts with American artists or impressionists, for example -, the market is not subject to the bias introduced by big museums, which tend to buy and "retire" some of the best works from the market. And third, the market for many of the most important Latin American artists is also quite liquid, with a large number of works by many of the masters being sold each year.

The rest of the paper is organized as follows: In Section II I discuss the main issues addressed in this paper, and I provide a brief review of the literature on the economics of art. In Section III I describe the data set. Section IV is devoted to the analysis of the creative process. The point of departure is Galenson's $(1997,2001)$ pioneering work on creativity patterns. In Section V I deal with Latin American art as an investment. I discuss methodological issues and I calculate hedonic price indexes to compute rates of return of different art portfolios. Finally, in Section VI I discuss directions for future research. There is also a data appendix where I provide a list of the artists included in this study.

\section{The Issues and the Literature}

Throughout the years a small number of economists have analyzed problems related to cultural issues. Some of the most important works in this field have dealt with the economics of museums, artistic competitions, artists and stardom, art auctions, investing in the arts and, more recently, with aspects of the creative process. Although work on the economics of art has never made it into the mainstream, many the authors involved in it have tended to be quite prominent in other fields. ${ }^{2}$

\section{II.1 The Creative Process of Artists}

In a series of recent works, David Galenson $(1997,1999,2001)$ has used data on auction prices and regression techniques to investigate creativity patterns among French and American painters from the $19^{\text {th }}$ and $20^{\text {th }}$ centuries. $^{3}$ In particular, Galenson has used

\footnotetext{
${ }^{2}$ Some prominent economists that have made their reputation in other fields and have published on the economics of art include William Baumol, Richard Caves, Sherwin Rosen and Orley Ashenfelter.

${ }^{3}$ See also Galenson and Weinberg (2000) and Galenson and Jensen (2002).
} 
these data to determine at what age different artists did their "best," or most important, work. In Galenson's regression analyses the dependent variable is the $(\log )$ of the price at which each work is sold; the independent variables include a polynomial on the age at which the work was executed, and data on the year when the work was sold. Additional covariates include the work's medium (canvas, board or paper) and its size. ${ }^{4}$ From this analysis Galenson is able to trace how prices for a particular artist are related to the artist's age when the work was painted. After analyzing his results Galenson argues that it is possible to distinguish two broad patterns of creativity among artists:

- Experimental artists: These artists peak late in life, and do their "best" work at an older age. For experimental artists each work is an experiment, and constitutes a step in a process of trial-and error. Experimental artists work slowly, and "rarely make preparatory sketches or plans for a painting" (Galenson 2001, p. 50). Paul Cezanne is an example of an experimental artist, which according to Galenson's (2001) analysis did his best work in 1906, when he was 67 years old.

- Conceptual artists: These artists work in a very different way than the experimentals. They conceive an idea - an artistic concept - and work on it until they have reached the desired result. During the creative process these artists do a number of sketches and studies, as they refine their concept and move towards the finished work. Conceptual artists are - or desire to be (sudden) innovators, and tend to do their best work early on in their careers. According to Galenson, Picasso is a very good example of a conceptual artist. Galenson's regression analysis suggests that Picasso did his "best" work in 1907, when he was 26 years old. That is the year when he finished Les Demoiselles d'Avignon.

In an important paper, Galenson and Weinberg (2000) used auction data to analyze creativity among American artists born between 1900 and 1940. They divided their data set into two cohorts: those artists born between 1900 and 1920 and those born

\footnotetext{
4 A number of economists have analyzed creativity within the context of R\&D, innovation and productivity. See, for example, Bartel and Sicherman (1998). Psychologists have had a long interest in
} 
between 1921 and 1940. According to their findings, based on a number of panel data regressions, artists belonging to the second cohort - that is, those born between 1920 and 1940 - tended to do their best work at a younger age than artists born before $1920 .^{5}$ For the pre-1920 cohort the estimated "peak age" -- or age when the most important work was executed - is 51 years; for the younger (post-1920) artists it is only 29 years of age.

Galenson and Weinberg argue that this significant shift in creativity patterns was mostly the result of a sudden increase in the demand for contemporary art in the $1950 \mathrm{~s}$ and 1960s. This change in the demand for works by contemporary American artists many associated with Abstract Expressionism - was (partially) the result of the increasing influence of critics such as Clement Greenberg, and by a new structure in the galleries' system. More and more galleries were willing to represent and support American artists - some of the most prominent early galleries included Pierre Mattise's, Julian Levy's and Peggy Guggenheim's --, and collectors' began spending increasing amounts on contemporary works. ${ }^{6}$ In the 1950 s and 1960 s many young artists found out that they didn't have to hold other jobs in order to survive. The increasingly dynamic galleries' system - including the new galleries - allowed them to devote all of their time to pursuing their artistic careers. ${ }^{7}$

Economists readily accept the proposition that, on average, prices reflect the value and quality of works of art. This view, however, is extremely controversial among the public in general, and art historians in particular. For this reason, Galenson $(1997,1999$, 2001) has made a major effort to show that the quality assessment extracted form a careful analysis of auction prices is not very different from what one obtains from an exhaustive reading of scholarly works by art historians and critics. In order to do this, Galenson analyzes a large number of scholarly works on art history published in the

\footnotetext{
understanding the dynamics of creativity. For a recent effort see Kanazawa (2003).

${ }^{5}$ Their data set includes 1,109 observations for the pre-1920 cohort, and 3,286 observations for the post1920 cohort.

${ }^{6}$ On the Julian Levy gallery see, for example, Levy (1977) and Schaffner and Jacobs (1998). On the Pierre Mattise gallery see Russell (1999), and on the "Art of this Century" run by Peggy Guggenheim in New York, see Guggenheim (1997).

${ }^{7}$ The galleries tended to pay their artists a (modest) stipend that allowed them to devote themselves fully to their artistic work. The stipend was paid back as their works were sold (in that sense, the stipend was equivalent to a writer's advance). A very small number of Latin American artists that were connected to New York's art world participated in this system, and received a stipend from their galleries. See Russell (1999) for the case of Cuban painter Wifredo Lam and Pierre Matisse's gallery.
} 
United States and Europe, and focuses on which works from specific artists are reproduced and discussed more often by the experts. ${ }^{8}$ He argues that this procedure allows him to extract information on which works, and "periods," in an artist's creative life are considered to be more important by scholars in the field. His analysis indicates that critics' judgements on artists" "best periods" and "best works" are extremely similar - almost identical, in fact -- from those obtained from his regression analysis.

\section{II.2 Art as an Investment}

Because works of art are unique, it is difficult to compare art prices at different points in time. Consequently, measuring the rate of return of art as an investment is nontrivial, and entails making a serious effort to compare the evolution of prices of "very similar objects." Economists have used two basic approaches to address this issue: (a) repeated sales; and (b) hedonic prices.

The repeated sales methodology consists of comparing prices of works that have been sold more than one time. By doing this, the analyst makes sure that the characteristics of the asset - in this case, the work of art - are exactly the same at different points in time. In a pioneering article, Baumol (1986) used this methodology to analyze the rate of return of "art" generally defined, and concluded that the annual return for the three centuries $1650-1960$ was $0.55 \%$ per year. ${ }^{9}$ Pesando (1993) calculated the rate of return on modern prints, and Pesando and Shum (1996) analyzed the case of Picasso prints. More recently, Mei and Moses (2001) have used the repeated sales techniques to estimate rates of returns on American paintings, old masters and impressionists. Although the repeated sales methodology has the advantage of calculating price indexes on the bases of strictly comparable assets, it has the limitation of not using all available information, and of averaging across artistic schools and/or artists in computing a single rate of return. ${ }^{10}$ One of the main limitations of this approach is that there are a many works of art that are sold only once within the sample period.

The use of hedonic prices allows the researcher to use information on all those transactions for which there are data, even if they refer to single sales. The hedonic price

\footnotetext{
${ }^{8}$ This methodology, which some times is referred to as "historiometry," has been used by a number of authors to evaluate intellectual accomplishments and eminence. See, for example, Murray (2003).

${ }^{9}$ In order to exclude "speculative" transactions, Baumol (1986) only included works that had been sold at least twice at, at least, 20 years intervals.
} 
methodology was developed in the 1930s as a way of comparing prices of automobiles with different characteristics, and has been used since to calculate price indexes of heterogenous commodities, including houses, computers and works of art. By using hedonic regressions the researcher is able to construct a price index for the "average" painting. "Average," in this case, is defined by maintaining constant a series of characteristics of the work, including the year it was painted, medium (paper, canvas or board), size, and whether the painting was signed by the artist. On hedonic prices in general see Berndt (1991), and the biography cited therein; on hedonic prices and the computation of price indexes for works of art see Barre et al (1994), Ashenfelter and Graddy (2003), and Chanel, Gerard-Varet and Ginsburgh (1996).

Most studies based on hedonic prices have calculated the rate of return for very broadly defined portfolios. For example, Anderson (1974), Buelenes and Ginsbourgh (1993), and Chanel, Gerard-Varet and Ginsburgh (1996) computed the rate of return of "paintings in general." Their results yielded an average (real) rate of return that ranged between 2.6\% and 4.9\%. Buelens and Ginsburgh (1993) used hedonic prices to analyze the rate of return of five paintings' portfolios: English painters, Non-English painters, Dutch painters, Italian painters and impressionists. Barre et. al (1996) looked at impressionists, and Czujack (1997) calculated the rate of return of Picasso paintings. There has been no hedonic price study - or repeated sales studies, for that matter - on Latin American painters.

From an investment strategy perspective, an important question is the degree of correlation of returns from investing in art, and from investing in other assets. More specifically, what is the effect of adding works of art on a portfolio's level of risk? This question has been addressed by a number of authors, including Goetzmann (1990) Pesando (1993) and Mei and Moses (2001). While some authors have analyzed the correlation of returns of art portfolios and securities' portfolios, other authors have estimated different versions of the CAPM model. Most of these studies have found that returns on (broadly defined) art portfolios have a low correlation with more traditional investment portfolios comprised of marketable securities only.

\footnotetext{
${ }^{10}$ This last criticism also applies to analyses based on the hedonic prices approach.
} 


\section{The Data Set}

In this paper I use a large data set on international auctions of Latin American works of art to analyze issues related to the creative process, and to investigate the performance of Latin American art as an investment. The total number of observations is 12,690. The data set covers 115 artist from 17 countries, for the period 1977-2001. In addition to the data from the international auctions themselves, I have assembled biographical data on all 115 Latin American artists included in the sample, including their nationality, date of birth, date of death (when relevant), artistic school and training. In most cases artists nationalities are given by place of birth; for a few artists, however, nationality is defined by the country where the artist lived and did (most) of her work. For instance, I have classified Remedios Varos as Mexican, even though she was born in Spain. Likewise, in this data set English-born Leonora Carrington is classified as Mexican. A complete list of artists is given in Table A.1.

The data on auctions are from two sources: (a) For 1977 through 1986 I used Leonard's Price Index of Latin American Art at Auction (Theran, 1999); (b) for 19872001 I used the ArtPrice CD-Rom. The following data were obtained from these two sources:

- Price at which the work was sold. Prices exclude the "buyer's premium.",1

- Year (and month) of sale.

- Place of sale.

- Auction house. Here I used a three-way classification: (a) Sotheby's (which was the house that pioneered Latin American Art auctions in 1979); (b) Christie's: and (c) other auction houses.

- Year in which the work was executed. When the work was done over a period of several years, the year when it was finished was considered.

- Size of the work, measured as length and width.

- Whether the work in question is a drawing or a painting. ${ }^{12}$

\footnotetext{
11 The original Leonard's Index data include the buyer's premium. In order to make the data compatible with that obtained from ArtPrice I subtracted the premium from prices obtained from Leonard's Index.

${ }^{12}$ In this paper paintings include work on canvas, board and paper, including watercolors, gouaches and pastels.
} 
- Whether paintings are on canvas, board or paper.

- Whether the artist has signed the work in question.

In order to be included in the data set, an artist has to have at least 35 works sold at international auctions during the period under study. ${ }^{1314}$ The mean number of works sold by each artist is 260 , and the median is 117 . Since not every work auctioned has information on every variable listed above, the number of observations used in the regression analysis was typically of the order of 6,000 to 7,000 .

The artists with the largest number of pieces in the data set are: Fernando Botero, Leonor Fini, Wifredo Lam, Roberto Matta, Carlos Mérida, Rene Portocarrero, Diego Rivera, Rufino Tamayo, Francisco Toledo, Joaquín Torres-Garcia, and Francisco Zuñiga.

Those artists with works sold in excess of US\$ 1 million are: Tarsila do Amaral, Fernando Botero, Frida Khalo, Wifredo Lam, Roberto Matta, Diego Rivera, Rufino Tamayo, and José María Velasco. In Table 1 I present summary data for the most important variables in the data set. The data on artists' lives and careers were obtained from a variety of sources, including Traba (1994), Theran (1999), Ades (1989), Barnitz (2001), Cardoza y Aragon (1974) and Castedo (1969).

While in the mid 1970s there were occasional auctions in the United States of works by Mexican artists, it was not until 1979 that a systematic system of international auctions was established (Martin, 1999). The first international auction exclusively dedicated to Latin American art was held at Sotheby's in New York in October of 1979. The total for that sale barely exceeded US\$ 1 million. ${ }^{15}$ In 1981 Christie's launched its own dedicated Latin American auctions, and since then both major houses have had twice-a-year auctions (May and October) in New York. In addition, smaller houses schedule regular auctions in other parts of the United States and in Europe.

\footnotetext{
${ }^{13}$ This criterion for inclusion in the data set is completely objective and data driven. In contrast, most earlier studies on the economics of art have relied on subjective criteria for including certain artists in the sample - for a discussion, see Barre et al (1994, p. 149).

${ }^{14}$ Since the data set has relatively few Brazilian artists in the data set, I made an exception to the rule, and included two artists from that country with a smaller number of works sold in international auctions.

${ }^{15}$ By comparison, each of the four yearly auctions currently held in New York by the two major houses, tend to bring in between US\$ 6 and US\$ 7 million.
} 
The fact that it was not until 1979 that periodic and dedicated international auctions were held, does not mean, however, that there was no interest in the United States or Europe for Latin American art. In fact, and contrary to what Martin (1999) asserts, in the United States a number of galleries had shown works by artists from Latin America as early as the 1930 s, and many collectors were interested in their work. For instance, Julian Levy exhibited Frida Khalo (Mexican) in 1938, Roberto Matta (Chilean) in 1940 and 1943, Rene Portacarrero (Cuban) in 1945, Jesús Guerrero Galván (Mexican) in 1943, and Rufino Tamayo (Mexican) in 1937 and 1938. Moreover, the Museum of Modern Art in New York had a number of large exhibits devoted to Latin American artists. In 1931 it had a major retrospective for Diego Rivera, and in 1957 it had a large show for Roberto Matta that was curated by William Rubin. In 1963 the Guggenheim Museum had a major show on promising young Latin American artists titled "The Emerging Decade," and in 1966 a major exhibit on Latin American art that covered the 1810-1960 period was shown at San Francisco Museum of Art. ${ }^{16}$ European galleries and museums also showed Latin American artists throughout the years. Jesús Rafael Soto (Venezuelan) had a one-man show at the Stedelijk Museum in 1968, Antonio Segui (Argentinean) was shown at the Musee d'Art Moderne de la Ville de Paris in 1979, and Matta had a major retrospective at Paris' Pompidou Museum in 1985.

In the Appendix to this paper I provide additional details about the data set used in the analysis discussed in the sections that follow.

\section{Patterns of Creativity: Comparing the Periphery and the Center}

For a long time scholars have been interested in understanding patterns of creativity. Why are some people more creative than others are? What makes someone a genius? At what age does creativity peak? And, is there a common age-pattern in creativity? While psychologists have been the most interested in understanding the creative process, scholars from other disciplines - including economists -have also dealt with this issue. In particular, a number of economists interested in understanding productivity growth have investigated the relationship between creativity and innovation

\footnotetext{
${ }^{16}$ The show was titled "Art of Latin America since Independence," and was also shown at the Yale University Art Gallery, the University of Texas Art Museum, the La Jolla Art Museum, and the Delgado Museum of Art in New Orleans.
} 
- see for example Griliches $(1979,1994)$. As pointed out in Section II of this paper, the issue of creativity among American and French artists has been analyzed in great detail in a series of pioneering contributions by Galenson $(1997,1999,2001)$ and Galenson and Weinbeg (2000) that used auction prices of works of art. It should be noticed, however, that in an earlier article Barre et al (1994) used auction prices to analyze at what period of their careers a group of six artists did their best work. The aim of their work, however, was more limited than that of Galenson and his co-authors, and they made no attempt to relate the age at which artists' best work was done with specific creativity patterns. ${ }^{17}$

In this section I use auction data to analyze creativity patterns among Latin American artists. More specifically, I am interested in investigating at what age Latin American artists - both individual artists, as well as groups of artists organized by cohorts - did their most important work. A particularly interesting question is whether the age-creativity pattern of Latin American artists experienced a shift similar to that observed among U.S. painters. As documented by Galenson and Weinberg (2000) the age at which American painters' executed their "best work" declined significantly for artists born after $1920 .^{18}$ In the rest of this section I proceed as follows. In Subsection IV.1 I describe the empirical methodology used to construct indexes of creativity patterns. In Subsection IV.2 I present results obtained from the computation of creativity patterns for what I call the "six big” Latin American artists: Diego Rivera, Wifredo Lam, Rufino Tamayo, Roberto Matta, Frida Khalo and Fernado Botero. In Subsection IV.3 I move to the estimation of age-creativity patterns for Latin American artists in three age cohorts: artists born before 1900, those born between 1900 and 1920; and those born after 1920 . Finally, in Section IV.4 I discuss future work on creativity patterns of Latin American artists.

\footnotetext{
${ }^{17}$ Table 5 of Barre et al (1994, p. 161) includes date ranges when the six authors in their sample experienced "good and ban spells."

${ }^{18}$ Whether Latin American artists' creativity patterns changed will depend on the evolution of the demand for Latin American art during the second half of the twentieth century. What is clear, however, is that in Latin America, and in contrast with the United States, no major and influential critics championed the regional younger artists. The possible exception was Marta Traba, an Argentine critic based in Bogotá. However, because Latin America's artistic world was - and to a large extent continues to be - largely fragmented, her influence was not the same across all countries. Traba died in an airplane accident in 1983. In 1994 the Interamerican Development Bank published her magnificent posthumous work "Arte de América Latina: 1900-1980.”
} 


\section{IV.1 The Empirical Model}

The question I am interested in is whether it is possible to identify at what age artists did their most important or best work. In dealing with this issue I follow Galenson (1997, 2001) and Galenson and Weinberg (2000), and I estimate regression equations that relate the (log of the) price of a particular work to a number of characteristics of the work in question, including a polynomial on the age at which the artist executed it. These equations were estimated both for the three cohorts mentioned above, as well as for individual artists. In the case of the three cohorts (pre-1900, 1900-1920, and post-1920), an unbalanced panel was used, and equations of the following type were estimated:

$$
\begin{aligned}
\ln \text { Price }_{\mathrm{jt}} & =\alpha_{1} \text { age }+\alpha_{2} \text { age }^{2}+\alpha_{3} \text { age }^{3}+\alpha_{4} \text { age }^{4}+\alpha_{5} \ln \text { height }+\alpha_{6} \ln \text { width } \\
& +\alpha_{7} \text { paper }+\alpha_{8} \text { signed }+\Sigma \beta_{\mathrm{i}} \text { year of sale dummy }+\Sigma \gamma_{\mathrm{i}} \text { artist dummy } \\
& +\Sigma \sigma_{\mathrm{i}} \text { decade dummy }+\varepsilon_{\mathrm{jt}} .
\end{aligned}
$$

Where the subscripts jt refer to painting " $j$ " sold in period "t." Price ${ }_{j t}$ is the price expressed in 1995 dollars. Age is the artist's age when the painting was executed, height and width capture the painting's size. Paper is a dummy variable that takes a value of 1 if the medium is paper and zero otherwise (when the medium is canvas, board or other support). Signed is a dummy variable that takes the value of one if the piece has not been signed by the artist, and takes a value of zero if it has been signed. The regressions also include a year of sale dummy, an artist dummy, and a decade dummy that is supposed to capture the possible existence of vintage effects. Finally, $\varepsilon_{\mathrm{jt}}$ is an error term. As discussed below, in the estimation of the panel regression (1) I make alternative assumptions regarding this error term.

The $\alpha_{1}$ to $\alpha_{4}$ coefficients on the age polynomial will determine the "pattern of creativity," or the relation between the artist's age when the painting is executed ant the painting's price (and quality). In order to determine the actual order of the polynomial I estimated models with polynomials of degrees 2 through 4 , and selected the specification with the highest polynomial where all estimated coefficients turned out to be significant.

Before presenting the results it is important to discuss some of the limitations of auction prices for this type of analysis (these limitations also apply to the rate of return 
calculations presented in Section V). Possibly the most important limitation is that there is a selection bias in the data. By definition, only those works that have been sold are included in the analysis - those that are "bought in" are not part of the data set, nor are works whose owners decide not to put on the block. Thus, the data set tends to exclude prices that are both on the upper and lower end of the distribution. Also, the data set is subject to an "omitted variables" problem; there are no data on some characteristics of the pieces sold, including whether they have been included in retrospectives, or their specific style. $^{19}$ In addition, auction prices exclude transaction costs - both the buyer's premium and the seller's commission. An additional limitation is that this data set has no direct information on the "supply" of works of art. Indeed, we don't know how many works each artist has produced per year, nor do we have information about his/her overall production. ${ }^{20}$ Moreover, as argued by Rosen (1974), hedonic price regressions do not capture demand characteristics; the coefficients obtained from hedonic estimations reflect both demand and supply forces.

Two additional limitations are particularly relevant for the analysis of rates of return presented in Section V: auctions are subject to very high transaction costs in the form of buyer's and sellers premia, transportation costs and insurance. This is not the case for financial assets. Finally, works of art yield a "dividend" in the form of satisfaction from owning them and being able to enjoy their beauty. This "dividend," however, is not measured by our data. The presence of these limitations does not mean, however, that auction prices have little information value. All it means is that results obtained using these data should be interpreted carefully.

\section{IV.2 Individual Patterns of Creativity for the "Big Six"}

I estimated equations of the type of (1) for the six individual artists that are usually considered the most important produced by Latin America: Diego Rivera, Wifredo Lam, Rufino Tamayo, Roberto Matta, Frida Khalo and Fernado Botero. With the exception of Botero, who was born in 1932, all of them were born before 1920; and Rivera and Tamayo were born before 1900. Table 2 summarizes some basic data for

\footnotetext{
${ }^{19}$ The style, however, is closely related to the year in which the piece was painted, and the data set does include information on dates when paintings were executed.

${ }^{20}$ However, when some variables related to supply --such as whether the artist is alive, or year of death --, the results do not change in any significant way.
} 
each of them, including number of paintings in the sample, average and median sale prices (in 1995 U.S. dollars), percentage of paintings executed on paper, and order of the estimated polynomial (for age of birth and death - if relevant - see Table A.1).

In Figure 1 I present the estimated price-age profiles for these six artists. The data on the horizontal axes refer to the artist's age; those on the vertical axes are on the $\log$ of prices, and are not comparable across artists. As may be seen, the age-price patterns are quite different for the "six big" artists. For Mexicans Diego Rivera and Rufino Tamayo, and for Cuban Wifredo Lam the schedule is first rising with age, until it reaches a peak; it then declines, reaching a trough, which is followed by a new ascending segment. For Tamayo and Lam the recovery continues until the time of their death. For Rivera, on the other hand, there is a plateau at 65 years of age, followed by a new decline; according to these calculations his latest works are the least important of his overall oeuvre. Although these three artists did their most valuable work at different ages, they all did it during the first half of their careers. According to the results, Rivera's best work was done when he was 31 years old; Tamayo did his most valuable work at 44 years old. Lam did his best work when he was 39 years of age, which corresponds approximately to the time when he painted his famous piece "The Jungle," currently in the permanent collection of the Museum of Modern Art. All in all, then, these three artists peaked quite early in their careers and, according to the discussion in Section II, can be classified as "conceptual" artists.

As Figure 1.D shows, Mexican artist Frida Khalo did her most valuable work when she was 38 years old (in 1945). That was the time when she painted some of her most famous self-portraits - including "Self-Portrait with Small Monkeys" --, and some of her best-known allegorical paintings, such as "Tree of Hope" and "The Broken Column." In contrast with Rivera, Tamayo and Lam, Khalo's very early work is more valuable than the work she executed a few years later. Indeed, according to Figure 1.D, the price-age relationship reaches a minimum at the time when she is 25 years of age. Although her most valuable work was done towards the end of her career - see the Figure --, she was quite young at the time, and, thus, she may also be classified as a "conceptual" artist. 
A simple visual comparison of the age-price profiles for Chilean Roberto Matta, and Colombian Fernando Botero shows that these are very different, and quite extreme. While in the case of the former there is a continuous decline in prices with age, in the case of Botero there is a continuous increase in prices with age. Although for neither artist the relationship is linear, for both of them the direction is unmistakable, and the maxima are at the extremes - at a (very) early age for Matta, and at an old age for Botero. Thus, Matta appears to be a quintessential case of a conceptual artist; Botero, on the other hand, is a prime example of an experimental artist.

According to these results, Matta's most important work was done in the late 1930s and very early 1940s, when he painted his psychological morphologies and psychological inscapes, and before he introduced the robotic-type characters that began to populate his work in the late $1940 \mathrm{~s}$ and $1950 \mathrm{~s}^{21}$ It is interesting to note that the pattern of strict decline that we observe in Matta's creativity pattern is quite unusual. For example, only 5 out of the 31 American artists analyzed by Galenson (1997) show this kind of behavior. Indeed, even artists such as Jasper Johns, whose pattern exhibits an overall decline through age, have marked inflections and local maxima at an older age. ${ }^{22}$ The case of Botero depicted in Figure 1.F is almost exactly the opposite to that of Matta. His early works - including his still lives and early portraits - are less important than his very recent works, where the motifs revolve around Colombia's society and people, and where a local narrative is always at the center of the composition. According to Figure 1, Botero is a very clear case of an experimental artist. Indeed, in a recent interview he recognizes that his work process does not include developing a series of preparatory sketches (Serena 2003).

\section{IV.3 Age Cohorts and Creativity Patterns of Latin American Artists}

In order to investigate whether there have been changes through time in Latin American artists' careers, I estimated a series of panel regressions of the type of (1) for three age cohorts. The first one corresponds to artists born before 1900. Most - but not all -- of these artists' work is traditional, and follows the European artistic cannon. Many

\footnotetext{
${ }^{21}$ He sometimes referred to these creatures as the "Great Transparents," an allusion to characters that appear in some of André Breton's writings.

${ }_{22}$ According to Galenson's results, Johns did his best work at the very beginning of his career, when he was 25 years old. There is, however, a local maxima in his mid 50s.
} 
artists in this group produced landscapes that capture the big vistas of their countries, as well as marine subjects. José María Velasco, from Mexico, is perhaps the best known and most prominent of this traditional group. A second group of Pre-1900 artists ventured into the late $19^{\text {th }}$ and early $20^{\text {th }}$ century European trends, including impressionism, fauvism and cubism - consider, for example, the early work by Diego Rivera. Finally, a small number of Pre-1900 artists developed very personal styles that, in many cases, became quintessential representatives of Latin American art. This is the case of the work by Rufino Tamayo, Joaquín Torres-García, Carlos Merida, and by the Mexican muralists - Diego Rivera, David Siqueiros, and José Clemente Orzco.

The second cohort corresponds to artists born between 1900 and 1920, and includes a wide variety of artists. Some of these have become iconic, including Frida Khalo and Wifredo Lam. Some of the better known artists in this group spent much of their careers away from their home country. That is the case of Wifredo Lam, who with the exception of a period in the forties and fifties lived mostly in France. The case of Roberto Matta is similar. After leaving his native Chile in the mid-1930s he never returned to it for a prolonged period of time. In fact, Matta's estrangement form his native country was so deep that some critics have referred to him as a French artist, born in Chile (Fletcher, 1992). In terms of artistic schools, this cohort exhibits a wide variety that includes abstract expressionism, figurative, surrealism, and constructivism, among other.

The third cohort corresponds to artists born after 1920. As in the previous two cases, this group includes representatives from a variety of artistic schools. There are some very prominent artists- including Fernando Botero, Francisco Toledo and Claudio Bravo --, and some that have played an important conceptual and intellectual role in the development of Latin American art. This is the case, for example, of Mexican José Luis Cuevas, who in 1956 wrote a manifest criticizing the then predominant trend in Mexico, of painting, almost exclusively, nationalistic - and revolutionary - scenes. In many ways, Cuevas' manifesto, which was titled "The Cactus Curtain," marked the beginning of the "Neofiguration" school among Mexican and Latin American artists. Cuevas' manifest provided a new intellectual framework to the very old debate among Latin American artists: should their work attempt to capture the region's realities, or should it 
be more 'universal' in its themes and subjects? Most scholars and art historians that have dealt with Latin American art discuss this issue, in one way or another. The history of the region's art movements is replete with "manifests" that dealt with questions such as "What is Latin American art?" and "What should be the artist's relation to Latin America's social realities?" Some intellectuals argued that Latin American artists should aim at producing a synthesis between European esthetic and artistic principles (especially modernism) and the regional realities. Possibly the most influential movement along these lines was "Antropofagia" developed by Oswaldo de Andrade and Tarsila de Amaral in Brazil. The famous and legendary "Week of Modern Art" that took place on February 13-18, 1922 in Sao Paulo gave the movement a great impulse. In 1924 - the same year Andre Breton published his "Surrealist Manifest" - Oswald de Andrade published his "Manifiesto de Poesía Pau-Brasil."

In addition to the three cohorts discussed here, I used alternative "breakpoints' to define the age groups. The results obtained, however, were very similar to those reported in this subsection. In Figures 2 through 4 I present the creativity patterns estimated for the three cohorts. These Figures were constructed from regression results estimated using weighted least squares, where the total number of works sold at auction by each artist are used as weights. When alternative estimation techniques are used, the results are very similar, however. ${ }^{23}$ As may be seen, these results show very different patterns across the three age groups:

- The relationship between the age at which the work was executed and prices exhibits an overall declining trend for the pre-1900 and 1900-1920 cohorts. This suggests that "conceptual" artists dominated these two cohorts.

- The patterns, however, are different for these two groups. While for the pre1900 cohort the maximum occurs at a very early age ( 23 years old), the maximum takes place at 31 years of age for the 1900-1920 cohort.

\footnotetext{
${ }^{23}$ Regressions were also estimated using Feasible Least Squares (FLS) and unweighted least squares. The results were very similar to those discussed here.
} 
- For the group born before 1900 , the schedule shows a decline in prices between ages 23 and 41 . From that point onward, and until age 65, the schedule exhibits a plateau of sorts.

- In contrast, for the cohort born after 1920 the price schedule is clearly upward sloping. In this case the maximum is achieved at 66 years of age, indicating the "experimental" artists have dominated this cohort.

These results suggest, then, that Latin American artists, as a group, moved from "peaking early" - a characteristic associated with "conceptual" artists - to peaking later and later in their careers. When formal tests for the equality of the coefficients of the age variables were performed, the results obtained confirmed that these cohorts of artists have (very) different creativity profiles. The F-test for the hypothesis of equality of coefficients between the pre-1900 and the 1900-1920 cohort has a value of 34.7; the F-test for the comparison between the pre-1900 and the post 1920 group is 129.4. Finally, the F-test for equality of coefficients for the 1900-1920 and post 1920 groups is 73.7. These results are very different from what Galenson has found for American and French artists. Indeed, and as discussed earlier, for these two groups of artists Galenson found that the age at which most important work was done had progressively moved earlier in time. Artists born after 1920 did their best work at a significantly younger age than their older colleagues (Galenson 2001, Galenson and Weinberg 2000).

The results for Latin American artists presented in Figures 2 through 4 imply that creativity profiles in the "periphery" have not changed through time in the same way as they changed in the "center." In many ways this should not surprise us, as the conditions under which the arts have developed in Latin American have been very different from those in the United States. Indeed, the three factors identified by Galenson and Weinberg (2000) as being behind the shift in creativity patterns in the U.S. - increased demand by collectors for "innovative" works, the influence of prominent critics, and a new galleries system - have been largely absent in Latin America.

In contrast with the United States, the history of Latin American art in the second half of the $20^{\text {th }}$ century has not been the history of artists searching for new ways of innovating. In Latin America, the greatest effort to innovate came early in the $20^{\text {th }}$ 
century, when Latin American artists struggled to find a voice of their own; it was an effort mostly undertaken by artists born before 1920. During the early decades of the last century, there was great interest in defining a type of art that could genuinely be considered as being "Latin American." This movement was largely based on the idea that the region's artists should find a synthesis between traditional precepts - mostly coming from Europe -, and the local realities. This search for a Latin American identity resulted in major artistic innovations during the 1920s, 1930s and 1940s, including the muralist movement in Mexico, "Antopofagia" in Brazil, and the "constructivist" school in the Rio de la Plata. Young artists that were willing to break with the academician heritage from Europe were at the forefront of this trend, and created new ideas on what Latin American artists should do. In Galenson's terms, these artists were largely "conceptual." They developed an artistic concept of what was genuinely Latin American. And, although, they were by no means a homogeneous group - indeed there were many differences among them --, they had in common the development of new visions that integrated artistic trends coming from the "center" and the "periphery." Diego Rivera, Rufino Tamayo, Tarsila de Amaral, Dr. Atl, Frida Khalo, and Wifreo Lam, are representatives of this group of artists that helped define Latin American art.

By the mid- $20^{\text {th }}$ century, a well-defined Latin American artistic voice had been established, and collectors began looking for variations of this perspective. As a result of this, younger artists began to improve on the, by then, well-accepted approach, and began experimenting with newer perspectives within the "Latin American voice". This resulted in a new creativity pattern for younger artists; they did their best work at a considerably older age than their rupturist older colleagues. The cases of Osvaldo Guayasamin and Fernando Botero are emblematic of this trend. To be sure, many artists in the second half of the $20^{\text {th }}$ century tried to break away from the Latin American canon developed during the previous decade, and in particular with what they considered to be an excessive representation of political - and in the case of Mexico, revolutionary -- themes. However, even these "rebellious" artists, such as Jose Luis Cuevas and his "neofiguration" colleagues, continued to relay on technique and craftsmanship - two characteristics associated with experimental artists --, when doing their work. To this day, collectors of Latin American art favor works with a strong regional content, based 
on distinctive Latin American voice and imagery. Indeed, as documented by Traba (1994) among others, during the 1950s, 1960s and 1970s - and in contrast with the case of the United States --, the Latin American public continued to prefer more traditional works. Only a very small group of adventurous collectors would pursue and purchase works by artists that were pushing the creative envelope. ${ }^{24}$

\section{IV.4 Artistic Creativity in Latin America: Directions for Future Work}

Future work in this area should go beyond "year of birth" as the main organizing principle in analyzing patterns of creativity among Latin American artists. Indeed, as I argued above, because in the 1950s and 1960s there were no major changes in the demand for Latin American art, or in the Latin galleries system, the distinction artists born before and after 1920 appears not to be very relevant. More promising lines of exploration are related to other characteristics of artists, including:

- The artistic (or esthetic) inclinations of the artist in question. In particular, comparing traditional (or 'indigenist') artists - or artists whose themes are unequivocally Latin American --, with "universalist" artists is a promising avenue. The Mexican muralists, Francisco Zuñiga, Tarsila de Amaral and Fernado Botero are representatives of the "traditionalist" trend; Roberto Matta, José Luis Cuevas and Gunther Gerszo, on the other hand, are "universalists."

- Artists with and without formal training abroad. This type of comparison would allow us to get some notion on the effects of artistic and "cultural exchanges" on creativity patterns. It will also shed some light on whether those that are trained abroad experience a noticeable "learning curve."

- Women artists versus male artists. Psychologists have traditionally argued that the creative pattern is different for men and women. In the case of Latin American art this comparison should be particularly interesting in light of the tremendous (posthumous) success of Mexican artist Frida Khalo.

\footnotetext{
${ }^{24}$ By this I don't mean to say that there were no true innovators among the younger artists. Jesús Rafael Soto is an important example. The arguments made above should be interpreted as referring to the general
} 
Preliminary results suggest that artists that have received formal training abroad tend to do their most important works at an older age than those with no foreign training. While for the former group the maximum (conditional) price of paintings is achieved at 37 years of age, for the latter group the maximum occurs at 23 years of age. These results also suggest that artists with former training experience a very steep learning curve: between the ages of 18 and 37 the price of their paintings increases very sharply with every additional year. With respect to "universalists" and "traditionalists," a preliminary regression analysis indicates that for the former group the most valuable work has been done at age 34. Traditionalists, on the other hand, exhibit a virtual "plateau" and their highest priced work is done between ages of 23 and 62 years of age.

\section{Latin American Art as an Investment}

In this section I use the data set described above to analyze Latin American art as an investment. As pointed out in Section II of this paper, two basic approaches have been used to analyze the rate of return of works of art: the "repeated sales" approach, and the "hedonic prices" approaches. In this paper I use hedonic prices, as this technique allows me to use all the available information and, thus, to obtain more precise estimates of the coefficients of interest. ${ }^{25}$ More specifically, I use panel regressions to compute hedonic price indexes for 13 different national portfolios. I then use these national results to calculate the rate of return (and standard deviation) of an overall portfolio of Latin American works of art. I finally analyze whether adding Latin American art reduces the overall level of risk of an international portfolio comprised of marketable securities.

Before discussing the hedonic price results, it is interesting to present some information on individual paintings that have been sold more that once during the period under study. Mexican artist Guther Gerszo's "Rojo, Azul y Amarillo," executed in 1966, was sold in 1985 for US\$12,000. It was again sold in 1992 for US\$ 38,000. Wifredo Lam’s 1943 painting "La Mañana Verde," was sold in 1987 for US\$ 380,000, in 1990 for US\$ 550,000, and in 1992 for US\$ 870,000. Finally, Roberto Matta’s 1942 canvas “The

\footnotetext{
trend among Latin American artists of different generations.

${ }^{25}$ Chanel et al (1992) compared the estimates obtained using the "repeated sales" and "hedonic prices" techniques. They found out that while the coefficients obtained using both methods are unbiased, those obtained using hedonic prices have a significantly smaller standard deviation.
} 
Disasters of Mysticism," was sold in 1983 for US\$ 160,000, and again in 1990 for US\$ 1.12 million, and in 1999 for US\$ 2.4 million.

\section{V.1 Hedonic Price Indexes and Rates of Return on National Portfolios}

The first step in the computation of rates of return consists of calculating an hedonic price index for a comparable "average" work of art. I used panel data to estimate equations of the following type for artists from thirteen different countries. ${ }^{26}$

$$
\begin{aligned}
\ln \text { Price }_{\mathrm{jt}}=\Sigma & \beta_{\mathrm{i}} \text { year of sale dummy }+\alpha_{1} \text { age }+\alpha_{2} \text { age }{ }^{2}+\alpha_{3} \text { age }^{3}+\alpha_{4} \text { age }^{4} \\
& +\alpha_{5} \ln \text { height }+\alpha_{6} \ln \text { width }+\alpha_{7} \text { paper }+\alpha_{8} \text { signed } \\
& +\Sigma \gamma_{\mathrm{i}} \text { artist dummy }+\sum \sigma_{\mathrm{i}} \text { decade dummy }+\varepsilon_{\mathrm{jt}} .
\end{aligned}
$$

The estimated $\beta_{\mathrm{i}}$ coefficients are the variables of interest. They provide information on the evolution through time of the (log of the) price of a work of art, maintaining constant (at their mean values) the characteristics of all other covariates including in the hedonic regression (2). In order to construct the hedonic price index, the $\beta_{\mathrm{i}}$ coefficient for the first year in the sample (1980 in this case) is normalized to one, and the rest of the coefficients are adjusted accordingly. ${ }^{27}$ I used this procedure to construct hedonic price indexes for the following national portfolios: Argentina, Brazil, Chile, Colombia, Cuba, Ecuador, Guatemala, Haiti, Mexico, Peru, Uruguay, Venezuela and "rest" of nationalities. I then used these data on national hedonic price indexes to compute rates of return of an equalvalue Latin American portfolio comprised of all thirteen individual national portfolios. ${ }^{28}$

The results obtained from this exercise are summarized in Figures 5 through 7. In Figure 5 I present the evolution of the hedonic price indexes for selected national portfolios. Figure 6 presents the evolution of the real rate of return in U.S. dollars of the equal-value overall - or "total" -- portfolio of Latin American works of art from 1981

\footnotetext{
${ }^{26}$ In rigor, I estimated hedonic price indexes for twelve national portfolios, and for a thirteenth portfolio that included artists from all other nationalities. See Figure 7 for details on the national portfolios.

${ }^{27}$ This procedure assumes that the coefficients of the other covariates in equation (2) are stable through time. This, however, needs not be the case. It is possible to compute hedonic prices assuming that these coefficients change through time. This requires using some type of chain-rule that links the different panel regressions for different periods.

${ }^{28}$ Using equals weights for calculating the "total" or "overall" portfolio's rate of return may provide figures that are not too realistic. The reason is that there are large differences in prices of individual pieces for
} 
through 2000. And, in Figure 7 I present the rates of return and standard deviation for the thirteen national portfolios as well as for the overall, or total, portfolio. As may be seen from Figure 6, between 1982 and 1990 annual (real) rates of return for the overall Latin American art portfolio were always positive and quite high. Between 1991 and 2000, the rates of return have been significantly lower, more volatile, and in a number of years they have been negative. For the total portfolio and complete 1981-2000 period, the overall mean annual (real) return was a hefty $9 \%$; the standard deviation was $12.6 \%{ }^{29}$ To put these figures in perspective, during the same period the following rates of (real) return and standard deviations were observed in selected emerging stock markets:

- Argentina: $\quad$ Return $=3.8 \% ; \quad$ Standard deviation $=57.3 \%$

- Brazil: $\quad$ Return $=7.3 \% ; \quad$ Standard deviation $=54.0 \%$

- Chile: $\quad$ Return $=7.3 \% ; \quad$ Standard deviation $=41.0 \%$

- $\quad$ South Korea: $\quad$ Return $=1.1 \% ; \quad$ Standard deviation $=55.0 \%$

- Mexico: $\quad$ Return $=5.5 \% ; \quad$ Standard deviation $=56.0 \%$.

Figure 6 shows that, as expected, there is a positive relationship between mean returns and risk. National portfolios with higher mean returns for the period under study tend to be precisely those with a higher standard deviation of returns. This figure also shows that, as expected, the diversified overall or "total" portfolio has a much lower degree of risk than the individual national portfolios. The important issue of the correlation between the rate of return of the Latin American portfolios and overall diversified world portfolios is addressed in subsection V.3.

\section{V.2 Thematic and Other Portfolios}

In addition to the national portfolios discussed above, I also computed hedonic price indexes, rates of return and standard deviations for a number of "thematic" portfolios, including portfolios for: (a) "Traditionalist" artists - or artists whose motives and imagery are quintessentially Latin American. (b) "Universalist" artists. (c) Artists with formal training abroad. (d) Artists with no formal training abroad. (e) Older artists

each of the national portfolios. For instance, average prices are quite for the case of Chile, and relatively low for the case of Haiti.

${ }^{29}$ Remember, however, that these figures are gross; they do not net out transaction costs. 
(born before 1900). (f) Artists born between 1900 and 1920 (Intermediate age artists). (g) Artists born after 1920 (Younger artists). And (g) women artists, excluding Frida Khalo. The results obtained are presented in Table 3 , and may be summarized as follows:

- "Traditionalist" portfolios have had a higher mean rate of return than "universalists."

- A portfolio of younger artists (born after 1920) has had higher rates of return than portfolios comprised of older artists. It has also had a lower standard deviation.

- Artists with formal training abroad had a slightly higher rate of return than portfolios of artists without training. It also had a slightly lower standard deviation.

- A portfolio of women artists (excluding Frida Khalo) had by far the highest annual mean rate of return - a quite remarkable $32.04 \%$. However, this portfolio has also had a standard deviation that is significantly higher than that of the other portfolios.

\section{V.3 The Correlation Between the Rate of Return Latin American Art and International Portfolios}

From an investment strategy perspective, an important question is the degree of correlation of returns on art and that of other assets. More specifically, what is the effect of adding works of art on a diversified portfolio's level of risk? Some authors have addressed this question by analyzing the correlation of returns of art portfolios and securities' portfolios, other authors have estimated different versions of the CAPM model. Most of these studies have found that returns on (broadly defined) art portfolios have a low correlation with more traditional investment portfolios comprised by marketable securities only.

I deal with this issue by estimating equations for the well-known capital asset pricing model (CAPM), which measures the degree of correlation of a particular asset (or asset class) and the "market" return. The standard CAPM equation regresses the excess 
return of the asset in question - measured as the difference between its return and that of a risk-free asset --, and the excess market return:

$$
\mathrm{R}_{\mathrm{t}}^{\mathrm{LA}}-\mathrm{r}_{\mathrm{t}}^{\mathrm{F}}=\alpha+\beta\left(\mathrm{R}_{\mathrm{t}}^{\mathrm{M}}-\mathrm{r}_{\mathrm{t}}^{\mathrm{F}}\right)+\varepsilon_{\mathrm{t}} .
$$

Where $R_{t}{ }_{t}^{L A}$ is the rate of return of the portfolio of Latin American artists, $r_{t}^{F}$ is the return on the risk-free asset, $\mathrm{R}_{\mathrm{t}}{ }^{\mathrm{M}}$ is the rate of return on the market portfolio, and $\varepsilon_{\mathrm{t}}$ is a whitenoise error term. The coefficient $\beta$ measures the degree of correlation of the art portfolio and the market portfolio. The lower the estimated "beta," the lower the correlation between the two portfolios, and the more attractive the Latin American portfolio will be. The reason for this is that "low-beta" portfolios (or securities) tend to lower the risk of a particular portfolio. I estimated equations of the type of (3) for a number of Latin American art portfolios. I used the three-month real return on U.S. Treasury bills as a measure of the risk-free rate, and the (real) return on the MSCI Wold Portfolio as a measure of the market return. I used the overall Latin American portfolio as a measure of $\mathrm{R}_{\mathrm{t}}^{\mathrm{LA}}$. The following results was obtained when equation (3) was estimated using ordinary least squares:

$$
\mathrm{R}_{\mathrm{t}}^{\mathrm{LA}}-\mathrm{r}_{\mathrm{t}}^{\mathrm{F}}=0.0548+0.108\left(\mathrm{R}_{\mathrm{t}}^{\mathrm{M}}-\mathrm{r}_{\mathrm{t}}^{\mathrm{F}}\right) ; \quad \text { D.W. }=1.4 ; \mathrm{N}=20 \text {. }
$$

As may be seen, the estimated beta coefficient is significantly lower than one, and not significantly different from zero. This indicates that adding Latin American art will reduce the riskiness of an international portfolio comprised of equities.

\section{Concluding Remarks}

In this paper I have used data on auction prices to investigate two aspects of the economics of Latin American art: (a) the relationship between age and creativity; and (b) Latin American art as an investment. The data set has more than 12,600 observations, and includes prices and other characteristics on sales of works by 115 artist from 17 countries during the period 1978-2001. 
The analysis on creativity suggests that Latin American artists have followed very different patterns than American artists. There is strong evidence suggesting that American artists born after 1920 did their best work at an earlier age than their colleagues born before 1920; exactly the opposite is true for the case of Latin America. Indeed, the results reported in this paper suggest that Latin American artists born after 1920 did their best work at a significantly older age than their colleagues from earlier cohorts. This difference in creativity patterns among these two groups of artists reflects differences in the market for American and Latin American art. Galenson and Weinberg (1920) have argued that in the U.S. there was an important increase in the demand for contemporary art in the 1950s and 1960s. Following the lead of influential critics, a new generation of American collectors began purchasing more and more works by American painters. These collectors put a big premium on innovation, thus pushing artists to do significant work at a relatively young age. The evolution of Latin American art has been very different. During the first half of the $20^{\text {th }}$ century Latin American artists struggled to find a voice of their own. This effort was largely based on the idea that Latin American artists should find a synthesis between traditional precepts - mostly coming from Europe -, and the region's realities. This search for a Latin American identity resulted in major artistic innovations in the region during the 1920s, 1930s and 1940s. Young artists that were willing to break with the academician heritage from Europe undertook most of these innovations. Diego Rivera, Rufino Tamayo, Tarsila de Amaral, Dr. Atl, Frida Khalo, Wifreo Lam, are representatives of this trend. These revolutionary artists did their best and most innovative -- work early on in their careers. By the 1950s, a well-defined Latin American artistic voice had been established, and collectors and critics began looking for variants of this perspective. As a result of this, younger artists began to improve on the well-accepted approach. Improvement came slowly, and took time. This resulted in a new creativity pattern for younger artists; they did their best work at a considerably older age than their rupturist older colleagues. The cases of Osvaldo Guayasamin and Fernando Botero are emblematic of this trend. (To be sure, many artists in the second half of the $20^{\text {th }}$ century tried to break away from the Latin American canon developed during the previous decade. Most collectors, however, continued to favor works with a strong regional content based on distinctive Latin American imagery.) 
The analysis of art as an investment was based on the estimation of hedonic price indexes, and indicates that Latin American art has had a relatively high rate of return indeed much higher than that of other type of paintings. But return comes at the cost of high volatility. Indeed, the standard deviations of national portfolios of Latin American art are quite high. The analysis presented here suggests that a thematic portfolio of female artists (excluding Frida Khalo) had the highest rate of return in the sample; it also had the highest standard deviation. From an investment strategy perspective, an important question is the degree of correlation of returns on art and that of other assets. More specifically, what is the effect of adding works of art on a diversified portfolio's level of risk? The results reported in this paper indicate that returns on Latin American art have a very low degree of correlation - that is a very low beta - relative to an international portfolio comprised of equities. This means that adding Latin American art will lower the overall risk of an international portfolio. 


\section{REFERENCES}

Ades, D. (1989), Latin America: The Modern Era 1820-1980. New Haven - London: Yale University Press.

Anderson, R.C. "Paintings as an investment," Economic Inquiry, 12,1: 13-26.

ArtPrice CD-Rom, 2002 Version.

Ashenfelter, O. and K. Graddy (2003), “Auctions and the Price of Art," Journal of Economic Literature, 61,3: 763-787

Barnitz, J. (2001), Twentieth Century Art of Latin America, University of Texas Press, Austin, texas.

Barre, M., S. Docclo and V. Ginsburgh (1996) "Returns of Impressionist, Modern and Contemporary European Paintings, 1962-1991," Annals of Economics Statistics, 35: 143181

Bartel, A.P. and N. Siicherman (1998), "Technological Change and the Skill Acquisition of Younger Workers," Journal of Labor Economics, 11, 1:162-183.

Baumol, W.J. (1986), "Unnatural Value: Art Investment as a Floating Crap Game," American Economic Review, 76: 10-14

Berndt, E.R. (1991), The Practice Of Econometrics: Classic Anti Contemporary (Reading, MASS: Addison-Wesley).

Buelenes, N. and V. Ginsburgh (1993), "Revisiting Baumol's Art as a Crap Game" European Economic Review, 37,7: 1351-1371.

Cardoza y Aragón, L. (1974), Pintura Contemporanea de México, Era, Mexico City.

Castedo, L. (1969), A History of Latin American Art and Architecture, Praeger, New York.

Channel, O., L.A. Gerard-Varet, and V. Ginsburgh, (1996), "The Relevance of Hedonic Price Indices," Journal of Cultural Economics, 20,1: 1-24.

Czujack, C. (1997), "Picasso Paintings at Auction, 1963-1994," Journal of Cultural Economics, 21,3: 229-247.

Fletcher, V. (1992), "Matta," in Crosscurrents of Modernism: Four Latin American Pioneers," Hirshhorn/Smithsonian, Washington, D.C. 
Galenson, D. W. (1997), “The Careers of Modern Artists: Evidence from Auctions of Contemporary Paintings,” NBER Working Paper 6331.

Galenson, D. W. (1999), "The Lives of the Painters of Modern Life: The Careers of Artists in France from Impressionism to Cubism," NBER Working Paper 6888.

Galenson, D. W. (2001), Painting Outside the Lines: Patterns of Creativity in Modern Art, Harvard University Press.

Galenson, D. W. and B. A. Weinberg (2000) "Age and the Quality of Work: The Case of Modern American Painters”, Journal of Political Economy, 108,4: 761-777.

Galenson, D. W. and R. Jensen (2002) "Careers and Canvases: The Rise of the Market for Modern Art in the Nineteenth Century", NBER Working Paper 9123

Goetzman, W. (1993), "Accounting for Taste: Art and Financial Markets Over Three Centuries," American Economic Review, 83,5: 1370-1376.

Griliches, Z. (1979). Issues in assessing the contribution of research and development to productivity growth. The Bell Journal of Economics. 10. Spring.

Griliches, Z. (1994). Productivity, R\&D, and the data constraint. The American Economic Review. 84(1). March.

Guggenheim, P. (Ed) (1997), Confessions of an Art Addict, Ecco, New York

Kanazawa, S. (2003) "Why Productivity Fades with Age: The Crime-Genius

Connection”, Journal of Research in Personality, 21,2:257-272.

Levy, J. (1977), Memoir of an Art Gallery, Putnam, New York

Lucie-Smith, E. (1993), Latin American Art of the 20th Century. Thames \& Hudson, London.

Martin, M.A. (1999), “The Latin Amewrican Market Comes of Age," in Theran, S. (Ed), (1999), Leonard's Price Index of Latin American Art at Auction, Auction Index, Newton. Mass.

Mei, J. and M. Moses, (2001), “Art as an Investment and the Origin of the 'Master-Piece Effect"” Working Paper, Stern School, NYU.

Murray, C. (2003), Human Accomplishments, Harper Collins, New York.

Pesando, J.E. (1993), “Art as an Investment: The Market for Modern Prints," American Economic Review, 83,5: 1075-89. 
Pesando, J.E. and P. Schum (1996), "Price Anomalies at Auction: Evidence from the Market for Modern Prints," in V. Ginsburgh and P.M. Menger (Eds), Economics of the Arts: Selected Essays, Elesevier, Ampsterdam: 113-134.

Rosen, S. (1974), "Hedonic Prices and Implicit Markets: Product Differentiation in Pure Competition," Journal of Political Economy, 82: 34-55.

Russell, J. (1999), Matisse: Father and Son, Henry Abrams, New York.

Schaffner, I. and L. Jacobs (Eds), (1998), Julian Levy: Portrait of an Art Gallery, MIT Press, Cambridge.

Serena, A. (2003), "Fernado Botero, Inigualable Maestro de las Formas," Nexos, AprilJune, 54-59.

Theran, S. (Ed), (1999), Leonard's Price Index of Latin American Art at Auction, Auction Index, Newton. Mass.

Traba, M. (1994), Arte de América Latina, 1900-1980, Interamerican Development Bank, Washington D.C.

Yale University (1969), Art of Latin America Since Independence, Yale University Art Gallery, New Haven. 
TABLE 1

Latin American Art Data Set:

Summary Statistics, 1978-2000

\begin{tabular}{|l|c|}
\hline Number of Artists & 115 \\
\hline Number of Countries & 206 \\
\hline Average Number of Paintings per Artist & 117 \\
\hline Median Number of Paintings per Artist & $\$ 39,996$ \\
\hline Average Price (in 1995 US Dollars) & $\$ 10,978$ \\
\hline Media Price (in 1995 US Dollars) & $78.9 \%$ \\
\hline Percentage Sold by Sotheby's and & 12,690 \\
\hline Christie's & \\
\hline Total Number of Observations & \\
\hline
\end{tabular}

Source: See text for details. 
TABLE 2:

Summary Statistics for the "Big Six" Artists

\begin{tabular}{|c|c|c|c|c|c|}
\hline Artist & $\frac{\text { Number of }}{\text { Paintings }}$ & $\frac{\underline{\text { Average }}}{\text { Price (1995 }}$ & $\begin{array}{l}\frac{\text { Median }}{\underline{\text { Price }}} \\
\text { (1995 US\$) } \\
\end{array}$ & 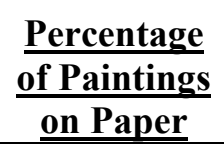 & $\underline{\text { Degree of }}$ \\
\hline $\begin{array}{l}\text { Fernando } \\
\text { Botero }\end{array}$ & 374 & 138,507 & 93,018 & $11.8 \%$ & 3 \\
\hline Frida Khalo & 40 & 576,702 & 149,391 & $14.6 \%$ & 4 \\
\hline Wifredo Lam & 495 & 69,417 & 22,397 & $26.1 \%$ & 3 \\
\hline $\begin{array}{l}\text { Roberto } \\
\text { Matta }\end{array}$ & 436 & 81,294 & 34,565 & $11.5 \%$ & 3 \\
\hline Diego Rivera & 471 & 108,392 & 27,932 & $52.4 \%$ & 4 \\
\hline $\begin{array}{l}\text { Rufino } \\
\text { Tamayo }\end{array}$ & 386 & 177,208 & 80,134 & $31.6 \%$ & 3 \\
\hline
\end{tabular}

Source: See text for details. 
TABLE 3:

Rates of Return and Standard Deviation for Alternative Portfolios of Latin American Art, $\underline{1981-2000}$ and 1985-2000

\begin{tabular}{|c|c|c|c|c|}
\hline portfolio & $\frac{\text { Mean }}{\underline{81-00}}$ & $\frac{\text { Stdev }}{\underline{81-00}}$ & $\frac{\text { Mean }}{\underline{85-00}}$ & $\frac{\text { Stdev }}{\underline{85-00}}$ \\
\hline Traditionalists & 0.0583 & 0.2190 & 0.0811 & 0.2140 \\
\hline Universalists & 0.0396 & 0.1909 & 0.0584 & 0.1934 \\
\hline Older (Pre-1900) & 0.0390 & 0.2071 & 0.0566 & 0.2001 \\
\hline Younger (Post-1920) & 0.0554 & 0.1826 & 0.0735 & 0.1877 \\
\hline Intermediate (1900-1920) & 0.0412 & 0.2144 & 0.0644 & 0.2015 \\
\hline Training & 0.0525 & 0.2053 & 0.0726 & 0.2105 \\
\hline NoTraining & 0.0491 & 0.2166 & 0.0618 & 0.2128 \\
\hline Women (Except Frida) & 0.3205 & 1.4000 & 0.2324 & 0.5010 \\
\hline
\end{tabular}

Source: See text for details 


\section{APPENDIX}

TABLE A.1: Artists in Data Set

\begin{tabular}{|l|c|c|}
\hline Artist & Birth & Death \\
\hline ABELA, EDUARDO & 1889 & 1965 \\
\hline ALFONZO, CARLOS & 1950 & 1991 \\
\hline AMARAL, TARSILA DO & 1886 & 1971 \\
\hline ANGUIANO, RAUL & 1915 & \\
\hline ATL, DR. & 1875 & 1964 \\
\hline BAZILE, CASTERA & 1923 & 1966 \\
\hline BERMUDEZ, CUNDO & 1914 & \\
\hline BERNI, ANTONIO & 1905 & 1981 \\
\hline BIGAUD, WILSON & 1931 & \\
\hline BONEVARDI, MARCELO & 1929 & 1994 \\
\hline BOTELLO, ANGEL & 1913 & 1986 \\
\hline BOTERO, FERNANDO & 1932 & \\
\hline BRAVO, CLAUDIO & 1936 & \\
\hline BUSH, NORTON & 1834 & 1894 \\
\hline CAMPO, FEDERICO DEL & 1837 & 1923 \\
\hline CANTU, FEDERICO & 1908 & 1989 \\
\hline CARDENAS, AGUSTIN & 1927 & 2001 \\
\hline CARRENO, MARIO & 1913 & 1999 \\
\hline CARRINGTION, LEONORA & 1917 & \\
\hline CASTAÑEDA, ALFREDO & 1938 & \\
\hline CASTAÑEDA, FELIPE & 1933 & \\
\hline CATALAN, RAMOS & $20 t h$ Cen. & n.a. \\
\hline CAVALCANTI, EMILIANO DE & 1897 & 1976 \\
\hline CHARLOT, JEAN & 1898 & 1979 \\
\hline CLAUSELL, JOAQUIN & 1866 & 1935 \\
\hline COLUNGA, ALEJANDRO & 1948 & \\
\hline CORONEL, PEDRO & 1923 & 1985 \\
\hline CORONEL, RAFAEL & 1932 & \\
\hline CORZAS, FRANCISCO & 1936 & 1983 \\
\hline COSTA, OLGA & 1913 & 1993 \\
\hline COVARRUBIAS, MIGUEL & 1904 & 1957 \\
\hline CUEVAS, JOSE LUIS & 1933 & \\
\hline DUFFAUT, PREFETE & 1923 & \\
\hline ENRIQUEZ, CARLOS & 1901 & 1957 \\
\hline ESCOBAR, MARISOL & 1930 & \\
\hline FERNANDEZ, AGUSTIN & 1928 & \\
\hline FIGARI, PEDRO & 1961 & 1938 \\
\hline FINI, LEONOR & 1996 \\
\hline GERZSO, GUNTHER & 2002 \\
\hline GRAU, ENRIQUE & 1998 \\
\hline GREENWOOD, MARION & 1970 \\
\hline GUAYASAMIN, OSWALDO & \\
\hline
\end{tabular}




\begin{tabular}{|c|c|c|}
\hline GUERRERO GALVAN, JESUS & 1910 & 1973 \\
\hline HERNANDEZ, DANIEL & 1856 & 1932 \\
\hline HORACIO, RENTERIA ROCHA & 1912 & 1972 \\
\hline HOYOS, ANA MERCEDES & 1942 & \\
\hline HYPPOLITE, HECTOR & 1894 & 1948 \\
\hline ITURRIA, IGNACIO DE & 1949 & \\
\hline IZQUIERDO, MARIA & 1902 & 1955 \\
\hline KAHLO, FRIDA & 1907 & 1954 \\
\hline KINGMAN, EDUARDO & 1913 & 1997 \\
\hline KUITCA, GUILLERMO & 1961 & \\
\hline LAM, WILFREDO & 1902 & 1982 \\
\hline LARRAZ, JULIO & 1944 & \\
\hline LAVILLE, HELENE JOY & 1923 & \\
\hline LEUUS, JESUS & 1948 & \\
\hline LOHR, AUGUST & 1843 & 1919 \\
\hline LYNCH, ALBERT & 1851 & 1930 \\
\hline MABE, MANABU & 1924 & 1997 \\
\hline MANUEL, VICTOR & 1897 & 1969 \\
\hline MARTINEZ, RICARDO & 1918 & \\
\hline MATTA, ROBERTO & 1911 & 2002 \\
\hline MERIDA, CARLOS & 1891 & 1984 \\
\hline MEZA, GUILLERMO & 1917 & 1997 \\
\hline MIJARES, JOSE & 1922 & \\
\hline MOLINA CAMPOS, FLORENCIO & 1891 & 1959 \\
\hline MONTENEGRO, ROBERTO & 1887 & 1968 \\
\hline MONTOYA, GUSTAVO & 1905 & n.a. \\
\hline MORALES, ARMANDO & 1927 & \\
\hline MORALES, DARIO & 1944 & 1988 \\
\hline NIERMAN, LEONARDO & 1932 & \\
\hline NORMIL, ANDRE & 1934 & \\
\hline OBIN, PHILOME & 1892 & 1986 \\
\hline OBIN, SENEQUE & 1893 & 1977 \\
\hline OBREGON, ALEJANDRO & 1920 & 1992 \\
\hline O'GORMAN, JUAN & 1905 & 1982 \\
\hline O'HIGGINS, PABLO & 1904 & 1983 \\
\hline OITICICA, HELIO & 1937 & 1980 \\
\hline OROZCO, JOSE CLEMENTE & 1883 & 1949 \\
\hline OROZCO ROMERO, CARLOS & 1898 & 1984 \\
\hline PELAEZ, AMELIA & 1896 & 1968 \\
\hline PENALBA, ALICIA & 1918 & 1982 \\
\hline PETTORUTI, EMILIO & 1892 & 1971 \\
\hline PIERRE, ANDRE & 1914 & 1979 \\
\hline POLEO, HECTOR & 1918 & 1989 \\
\hline PONCE DE LEON, FIDELIO & 1895 & 1949 \\
\hline PORTINARI, CANDIDO & 1903 & 1962 \\
\hline PORTOCARRERO, RENE & 1912 & 1986 \\
\hline QUINQUELA MARTIN, BENITO & 1890 & 1977 \\
\hline RAMOS, DOMINGO & 1894 & 1967 \\
\hline RAMOS MARTINEZ, ALFREDO & 1871 & 1946 \\
\hline
\end{tabular}




\begin{tabular}{|c|c|c|}
\hline REVERON, ARMANDO & 1889 & 1954 \\
\hline RIVERA, DIEGO & 1886 & 1957 \\
\hline RODO BOULANGER, GRACIELA & 1935 & \\
\hline RODRIGUEZ, MARIANO & 1912 & 1990 \\
\hline ROJAS, ELMAR & 1939 & \\
\hline ROMAÑACH, LEOPOLDO & 1862 & 1951 \\
\hline SANCHEZ, EMILIO & 1921 & \\
\hline SANCHEZ, TOMAS & 1948 & \\
\hline SEGUI, ANTONIO & 1934 & \\
\hline SIQUEIROS, DAVID ALFARO & 1896 & 1974 \\
\hline SORIANO, JUAN & 1920 & \\
\hline SOTO, JESUS RAFAEL & 1923 & \\
\hline SZYSZLO, FERNANDO DE & 1925 & \\
\hline TAMAYO, RUFINO & 1899 & 1991 \\
\hline TOLEDO, FRANCISCO & 1940 & \\
\hline TORRES-GARCIA, JOAQUIN & 1874 & 1949 \\
\hline VARELA, ABIGAIL & 1948 & \\
\hline VARO, REMEDIOS & 1908 & 1963 \\
\hline VELASCO, JOSE MARIA & 1840 & 1912 \\
\hline VELASQUEZ, JOSE ANTONIO & 1906 & 1985 \\
\hline VILLACRES, CESAR A. & 1880 & n.a. \\
\hline ZARRAGA, ANGEL & 1886 & 1946 \\
\hline ZUNIGA, FRANCISCO & 1912 & 1998 \\
\hline
\end{tabular}

Source: See text for details. 


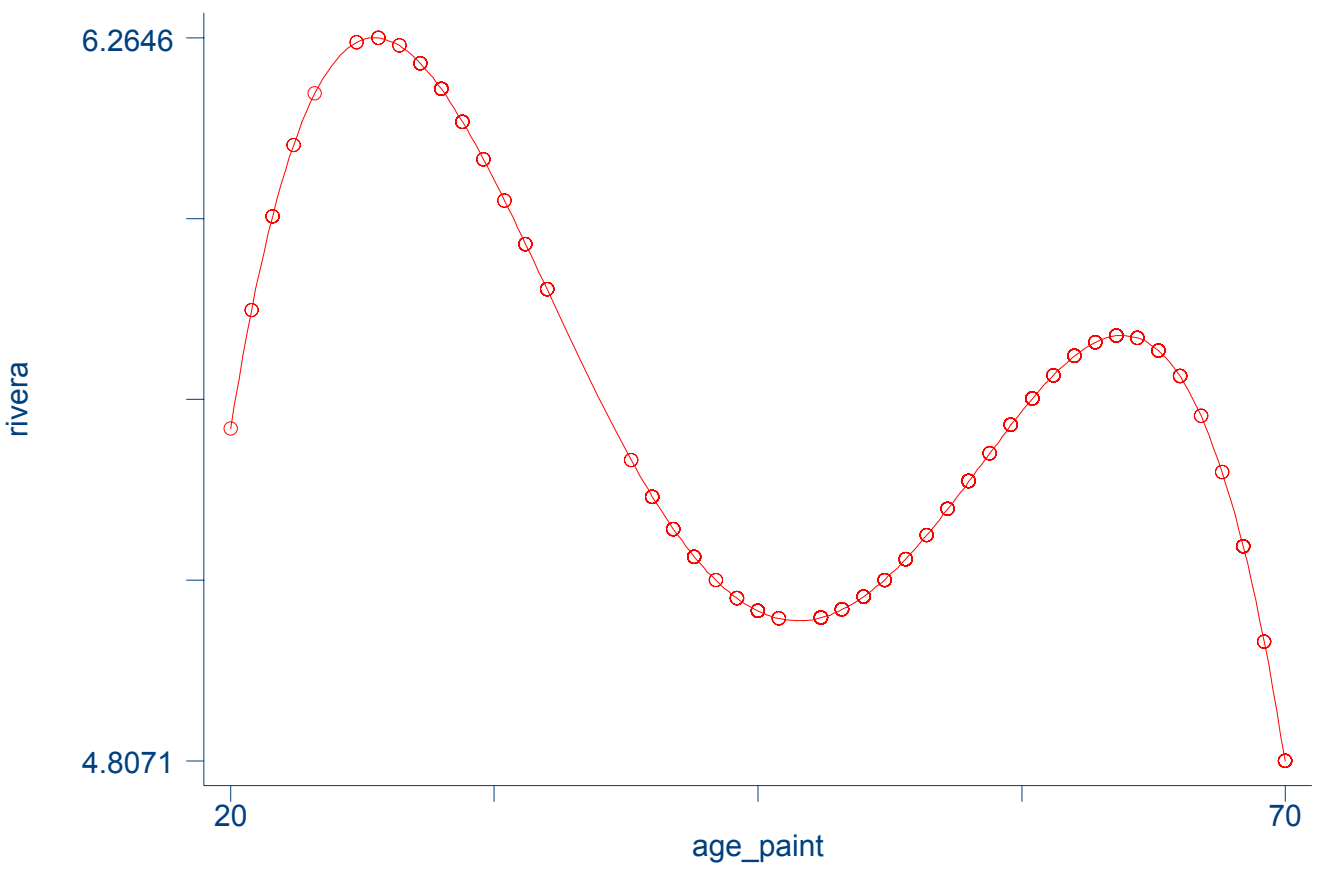

A. Diego Rivera

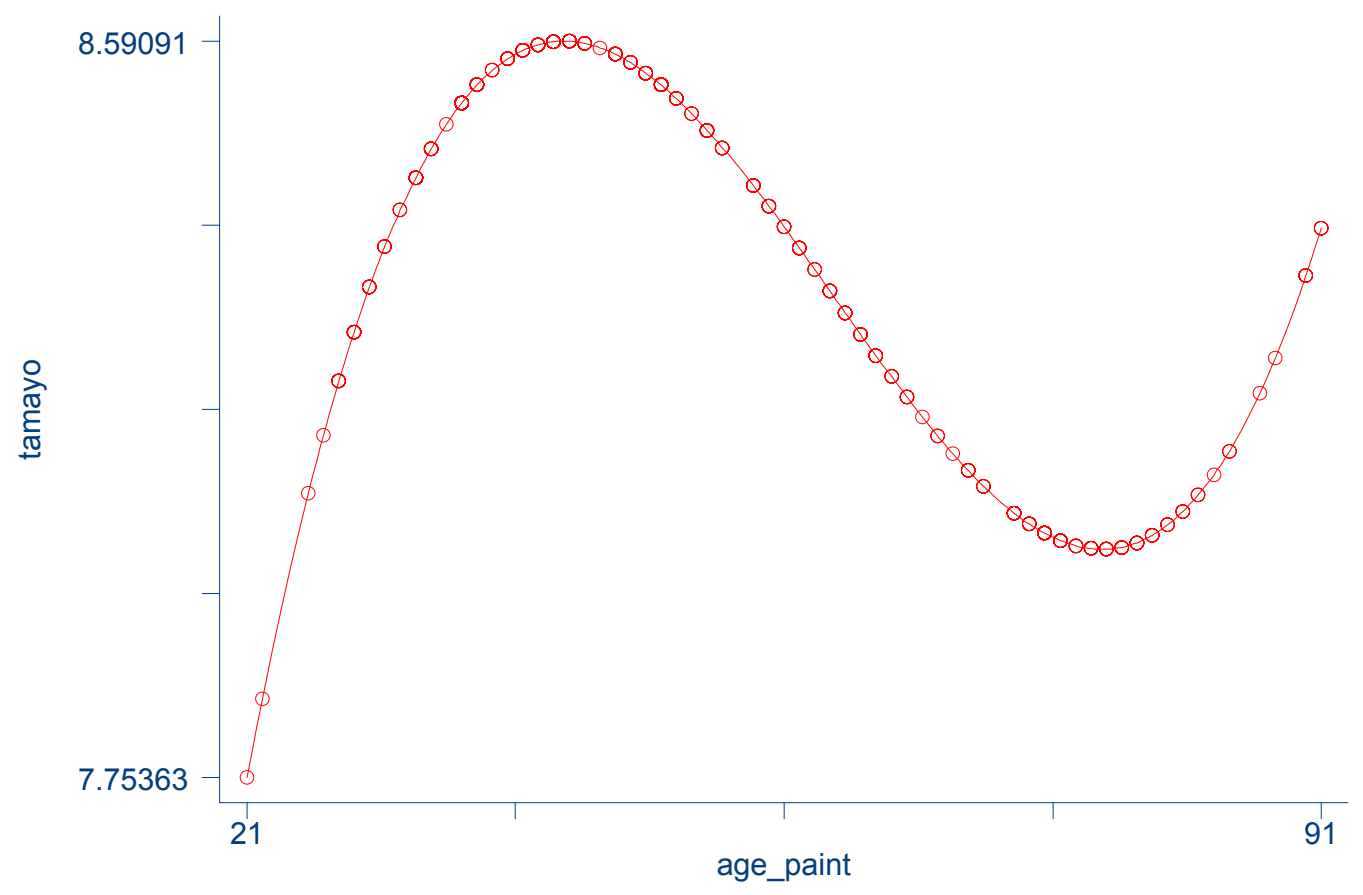

B. Rufino Tamayo 


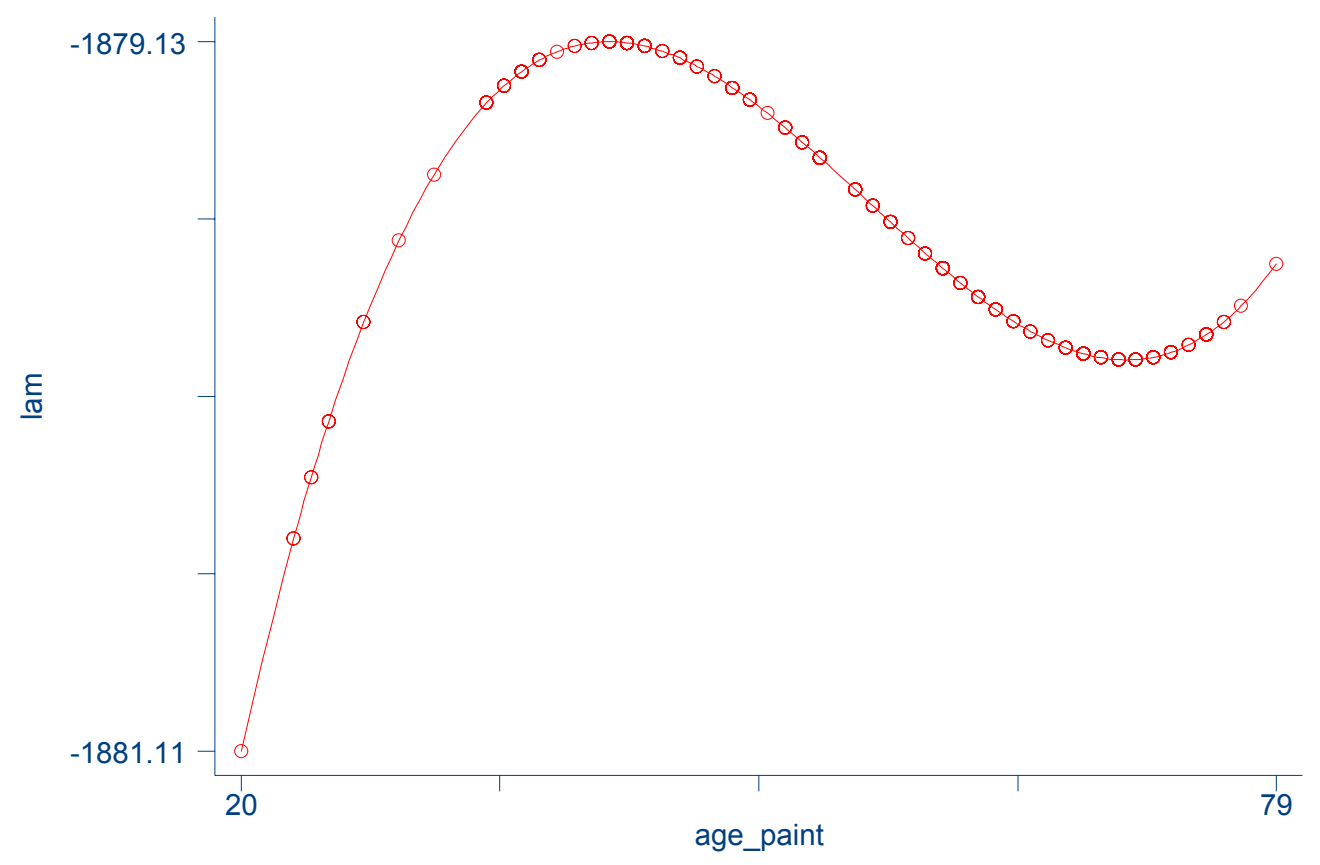

C. Wifredo Lam

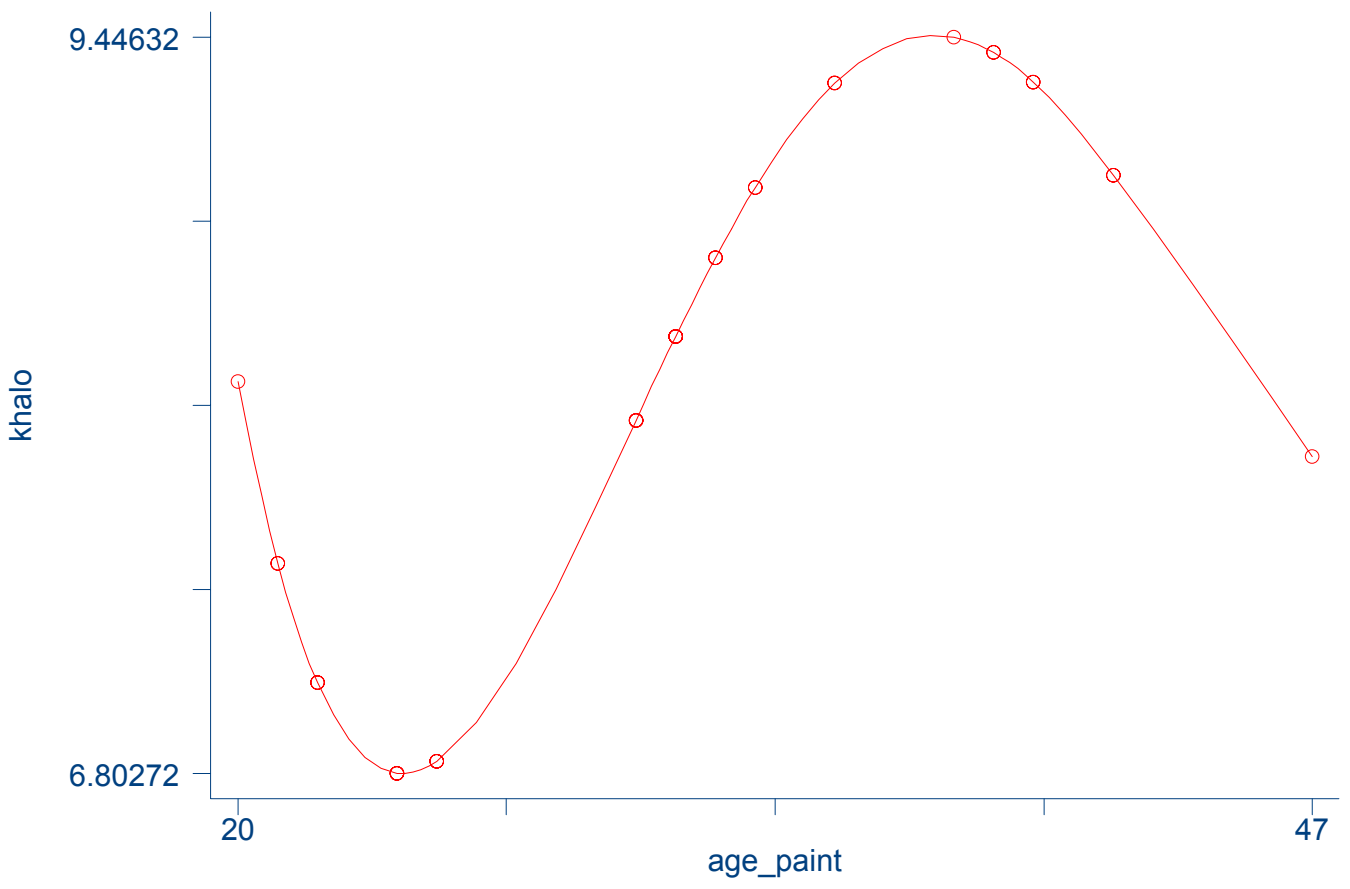

D. Frida Khalo 


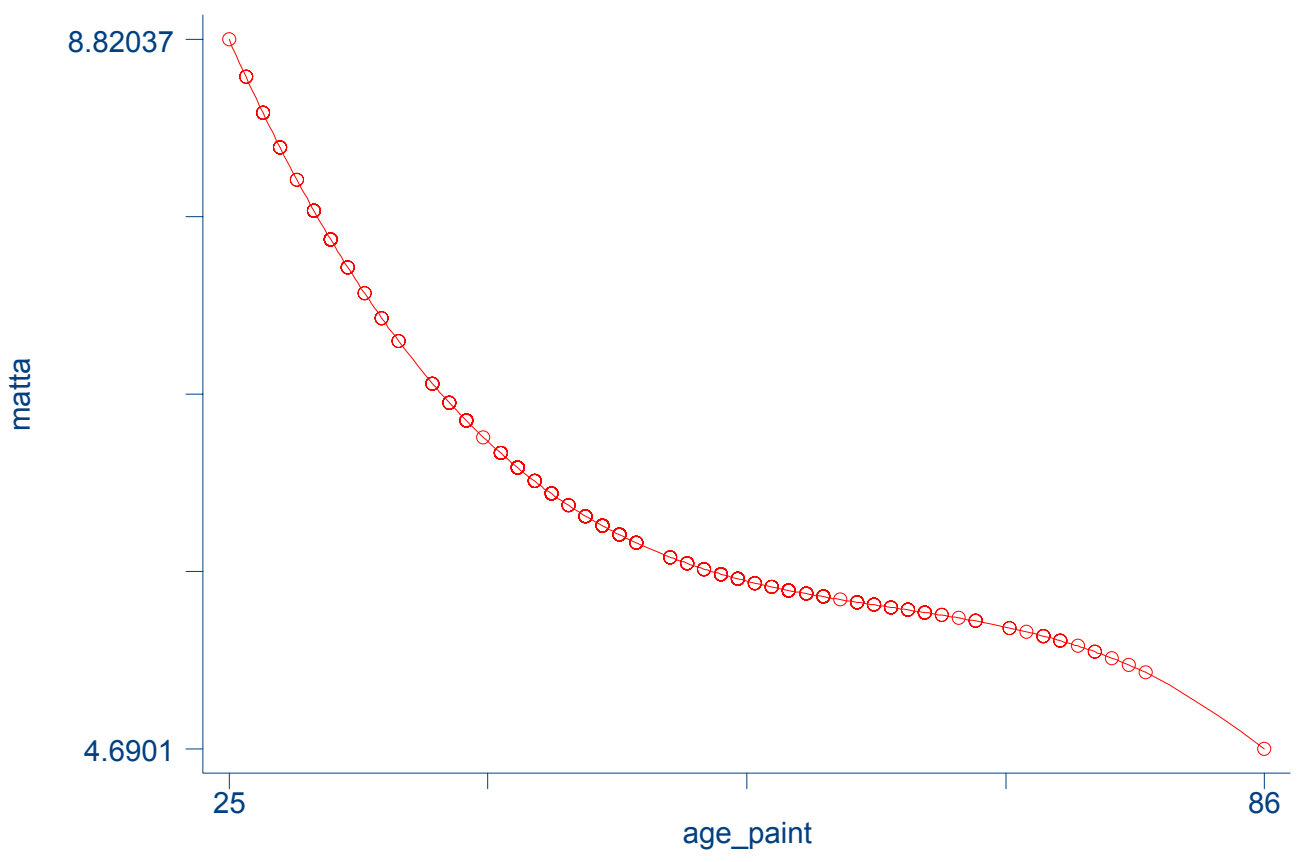

E. Roberto Matta

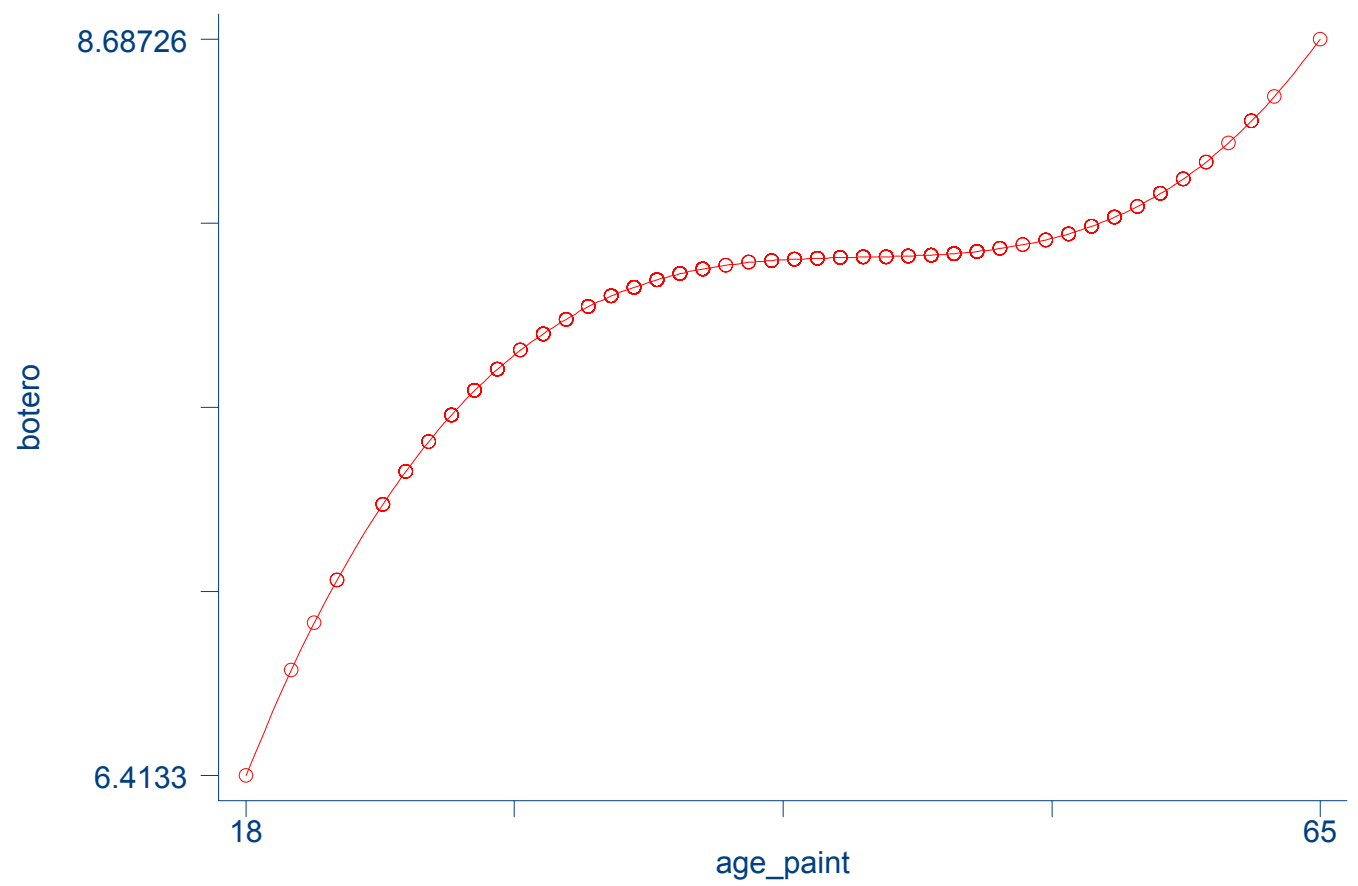

F. Fernado Botero

FIGURE 1: Creativity Patterns of the "Big 6" 


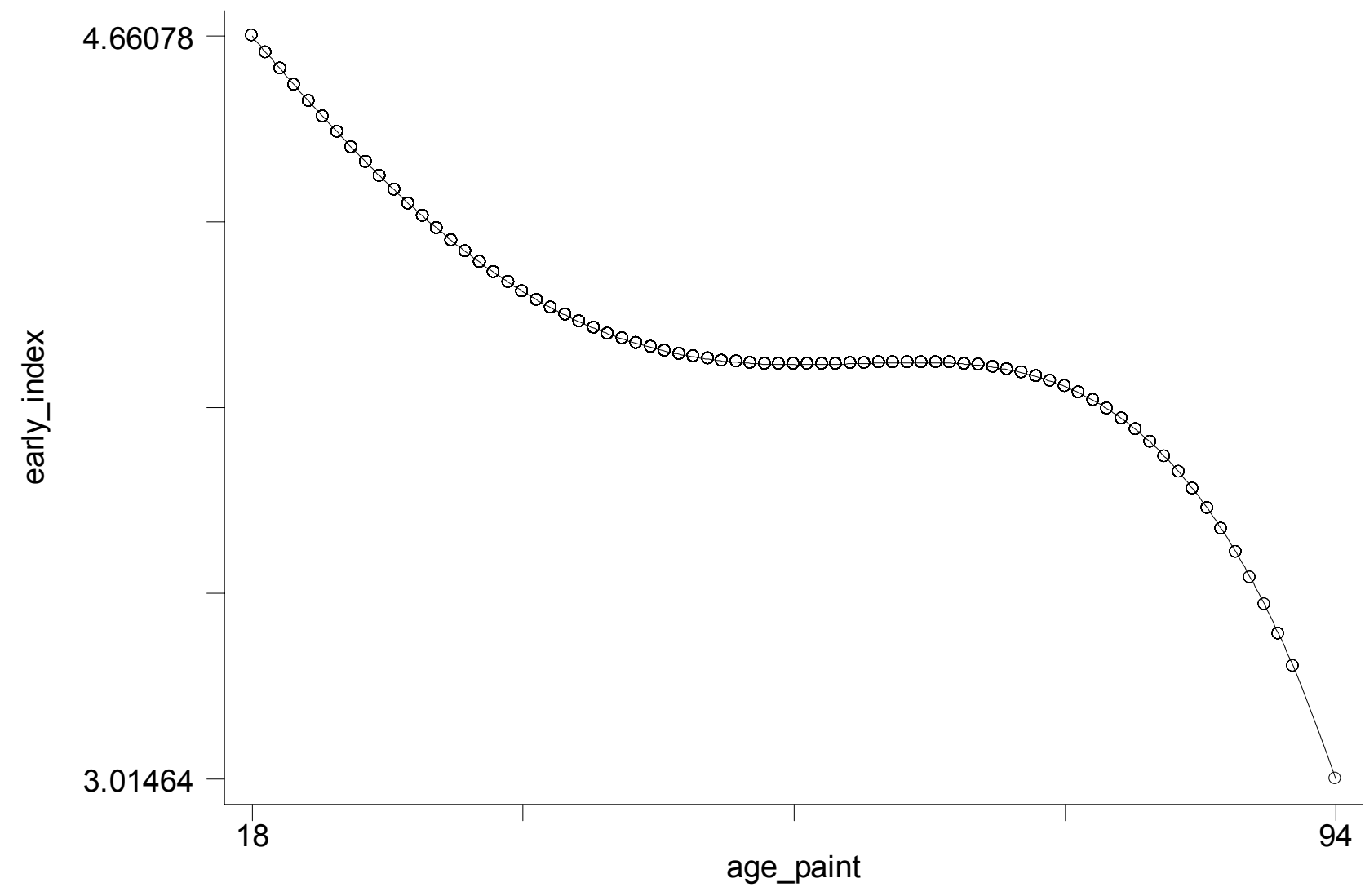

Figure 2: Creativity Pattern for Pre-1900 Cohort 


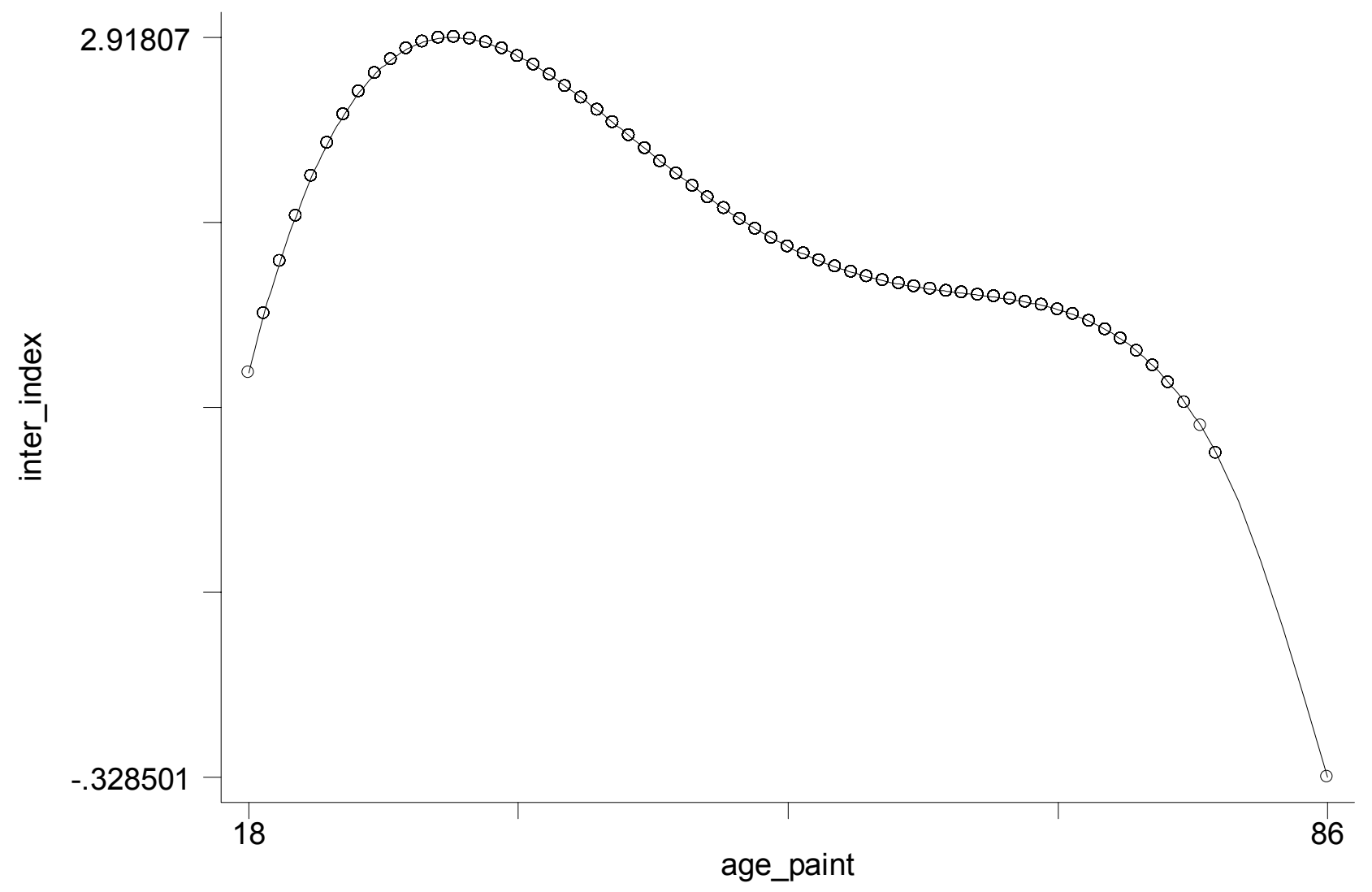

Figure 3: Creativity Pattern for 1900-1920 Cohort 


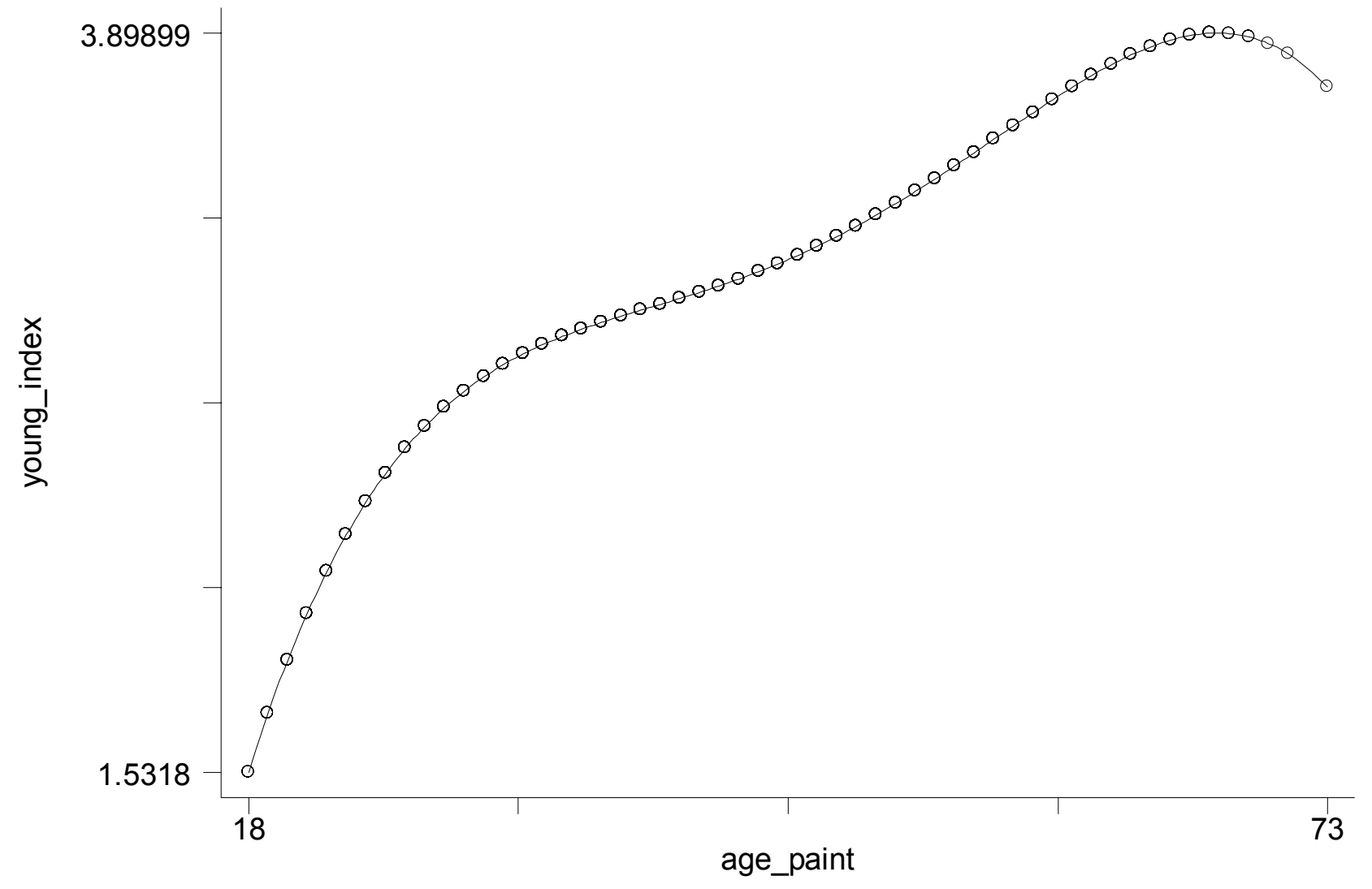

Figure 4: Creativity Pattern for Post-1920 Cohort 


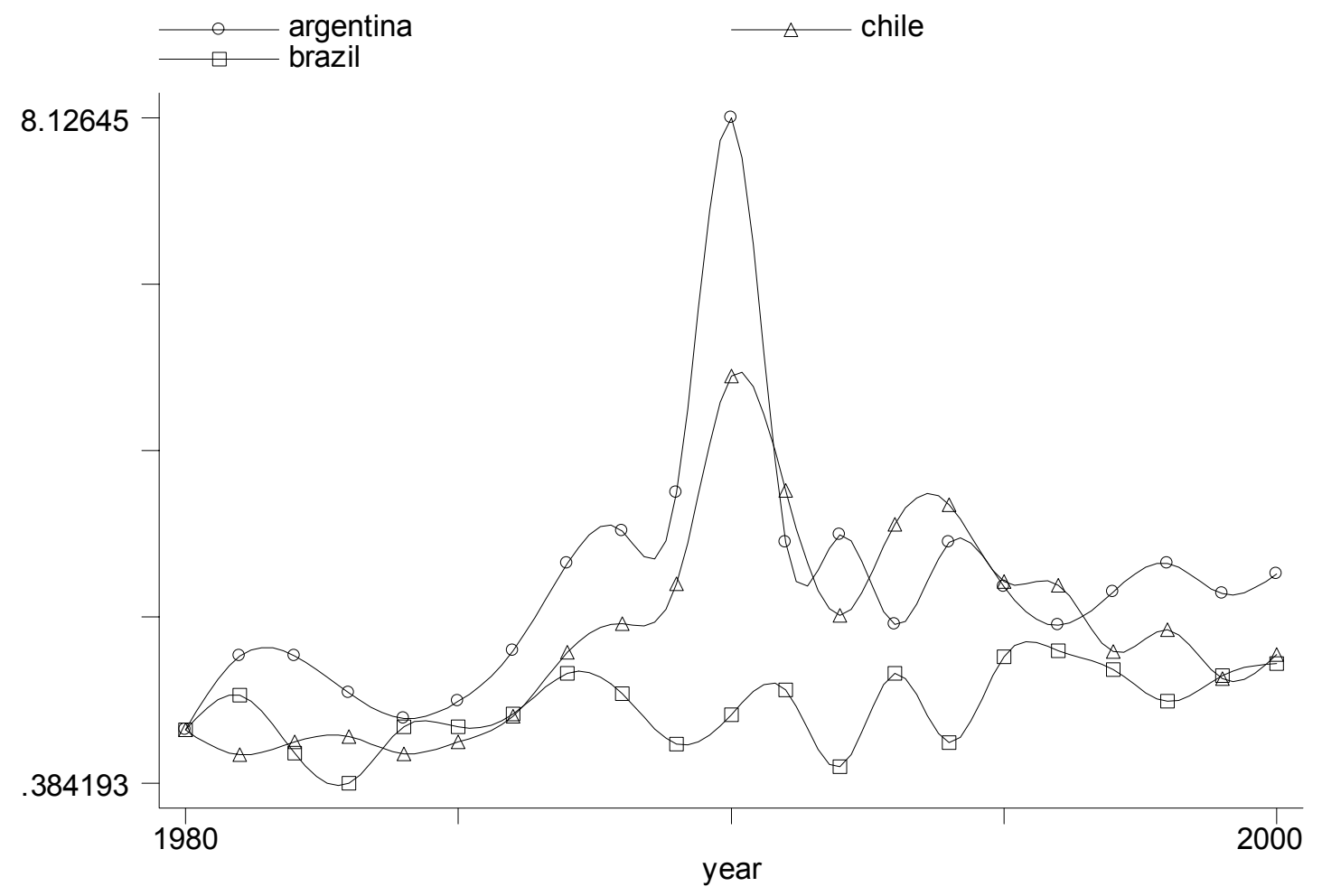

Figure 5A: Hedonic Price Indexes for Selected Portfolios (Argentina, Brazil, Chile) 


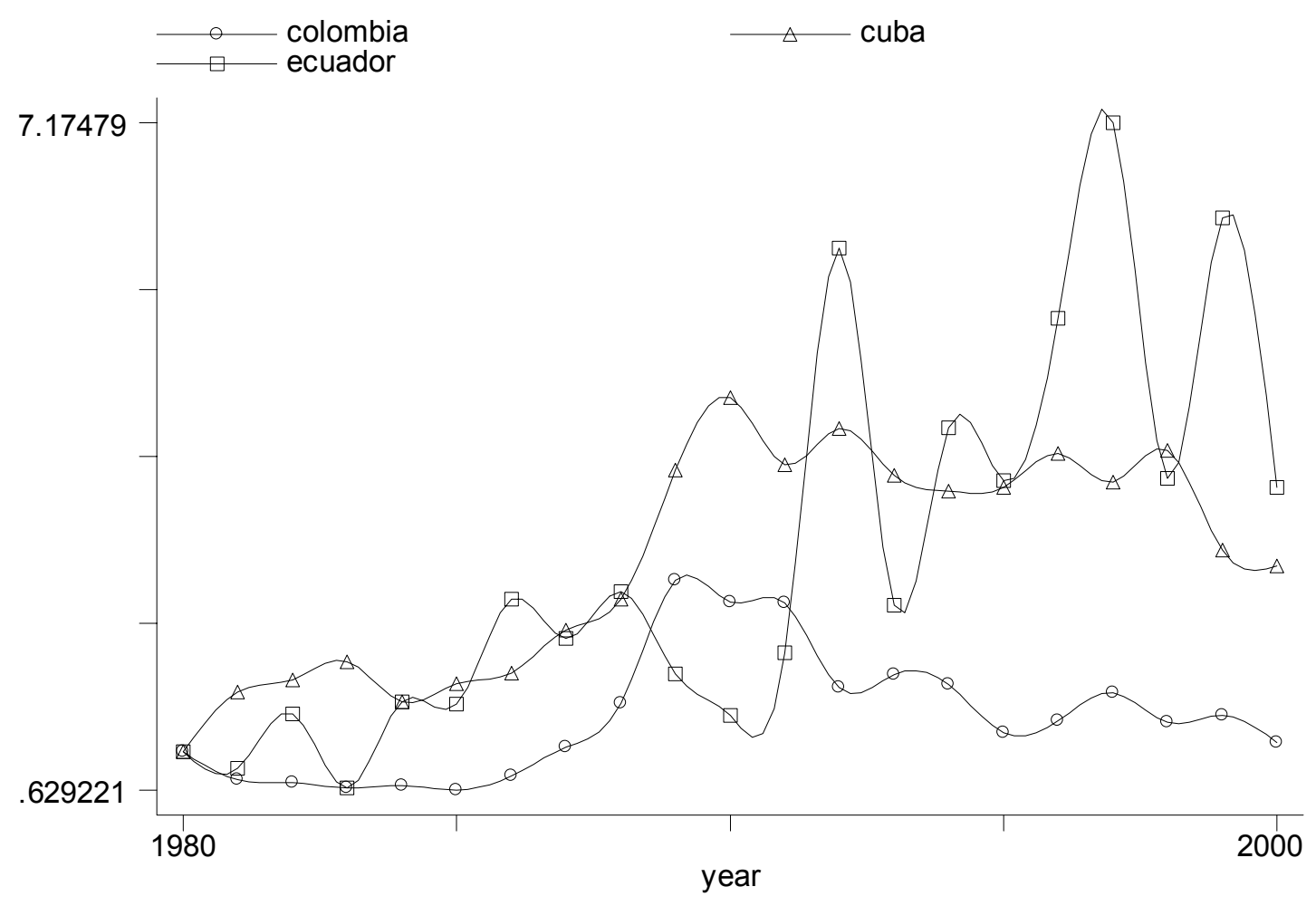

Figure 5B: Hedonic Price Indexes for Selected Portfolios (Colombia, Cuba, Ecuador) 


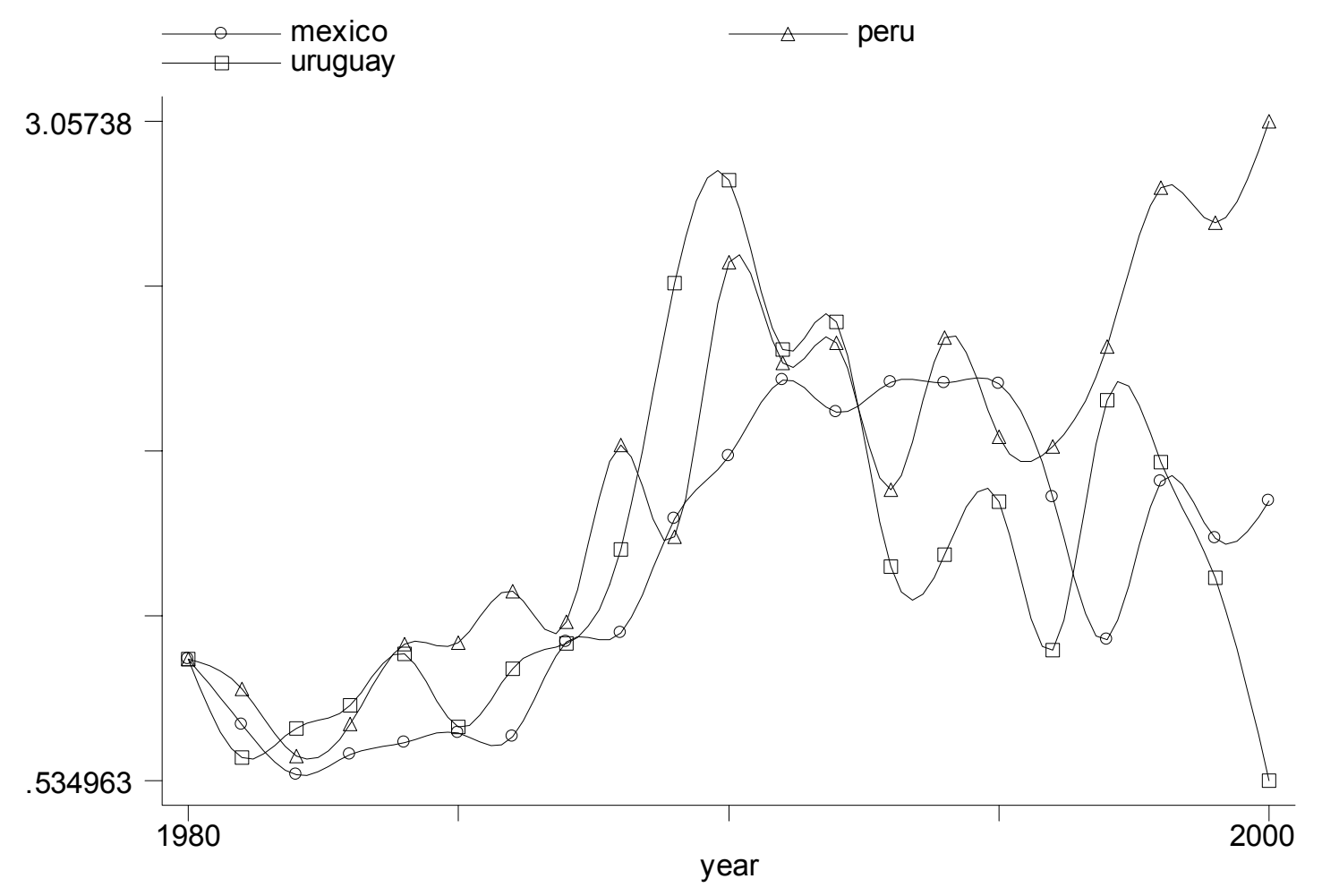

Figure 5A: Hedonic Price Indexes for Selected Portfolios (Mexico, Peru, Uruguay) 


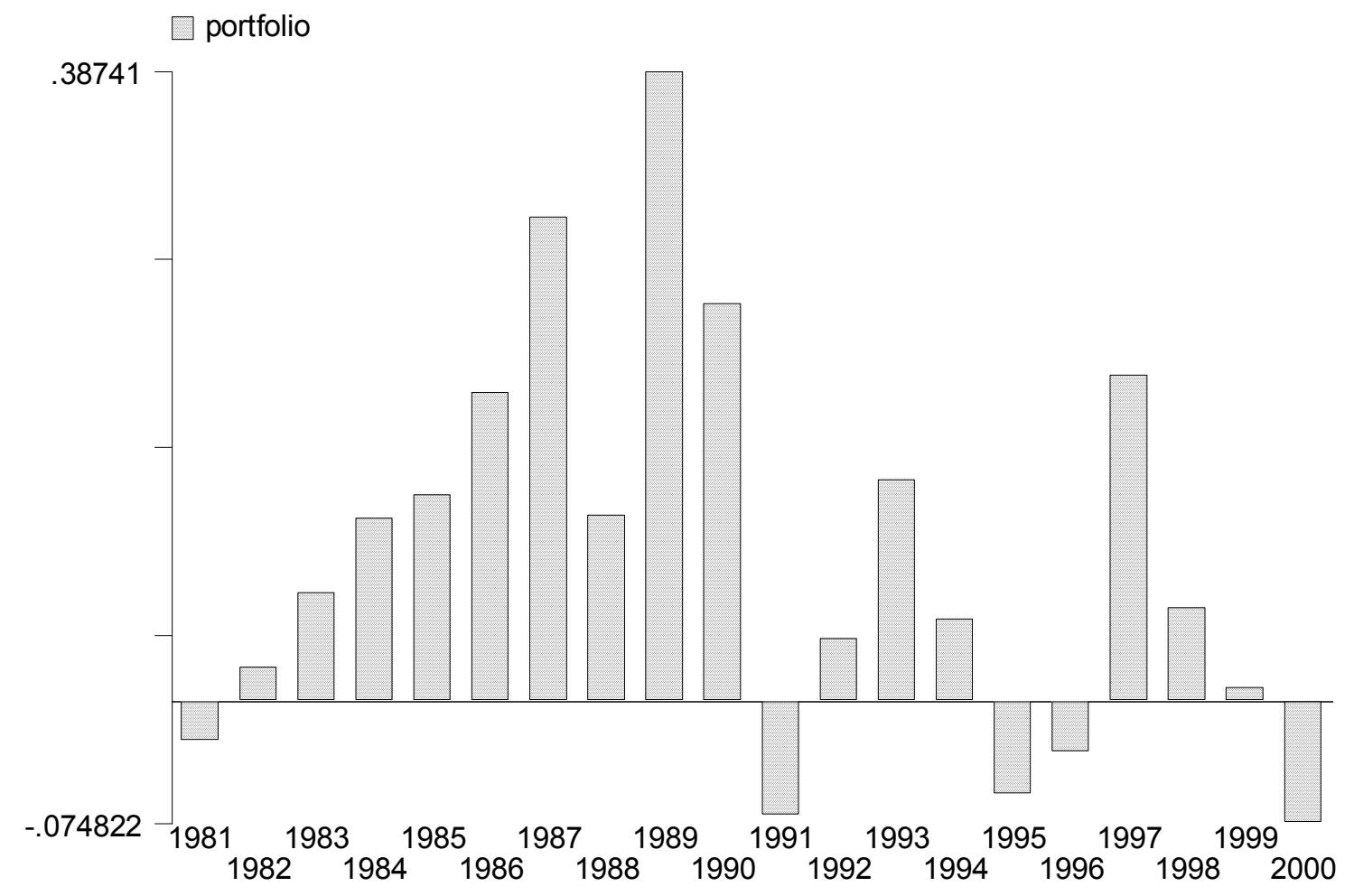

Figure 6: Annual real rates of Return: Overall Portfolio of Latin American Artists 


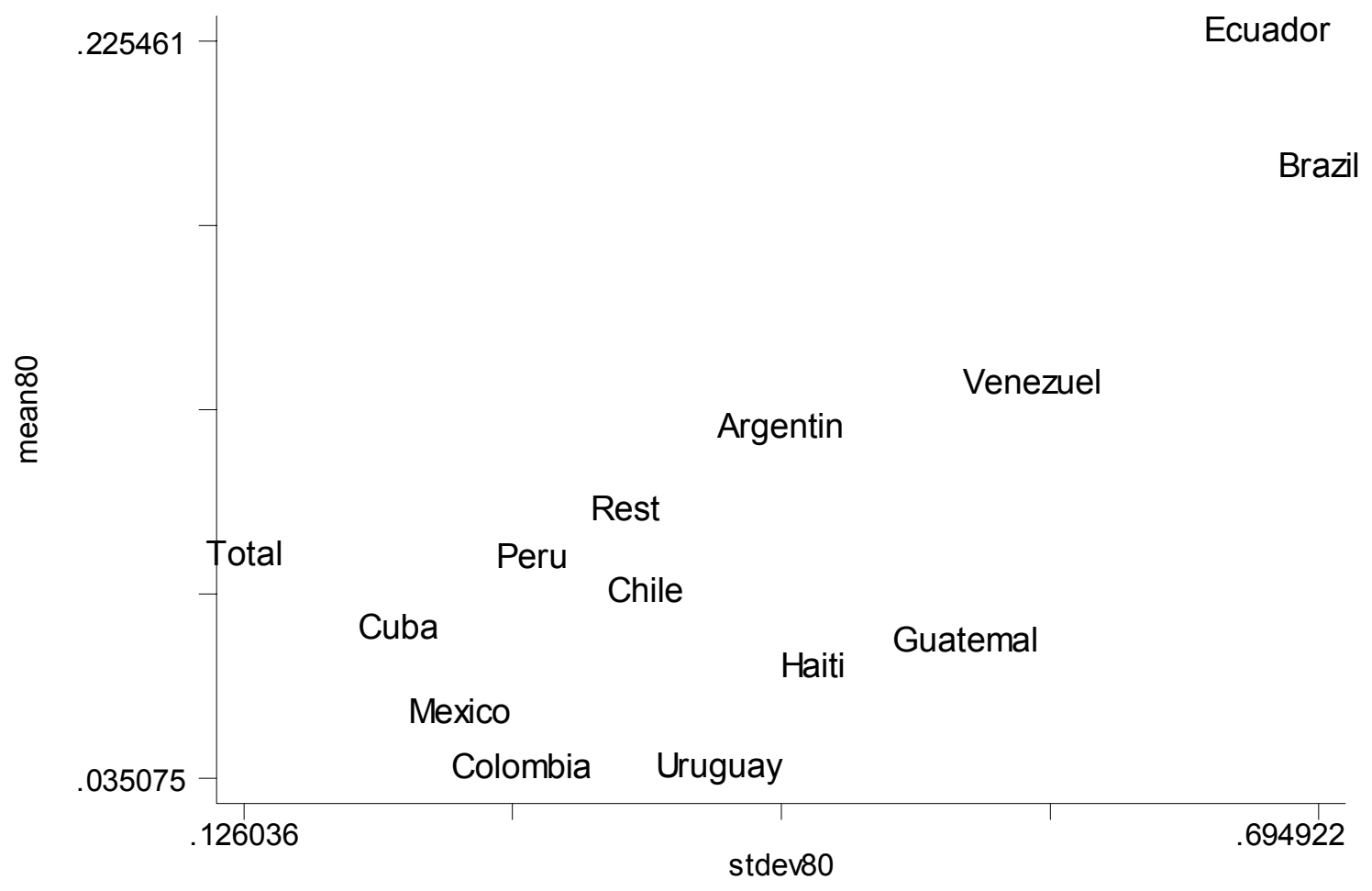

Figure 7: Risk and Return: National Artists Portfolios (Real US\$, 1981-2000) 